Florida International University FIU Digital Commons

FIU Electronic Theses and Dissertations

University Graduate School

$11-22-1996$

\title{
Exchange rate overvaluation under hyperinflation : the case of Peru
}

Rafael Amiel-Saenz

Florida International University

DOI: $10.25148 /$ etd.FI14032307

Follow this and additional works at: https://digitalcommons.fiu.edu/etd

Part of the International Economics Commons

\section{Recommended Citation}

Amiel-Saenz, Rafael, "Exchange rate overvaluation under hyperinflation : the case of Peru" (1996). FIU Electronic Theses and Dissertations. 1279.

https://digitalcommons.fiu.edu/etd/1279

This work is brought to you for free and open access by the University Graduate School at FIU Digital Commons. It has been accepted for inclusion in FIU Electronic Theses and Dissertations by an authorized administrator of FIU Digital Commons. For more information, please contact dcc@fiu.edu. 
Miami, Florida

EXCHANGE RATE OVERVALUATION UNDER HYPERINFLATION:

THE CASE OF PERU

A dissertation submitted in partial satisfaction of the requirements for the degree of

DOCTOR OF PHILOSOPHY

IN

ECONOMICS

by

Rafael Amiel-Saenz 
To: Arthur Herriott

College of Arts and Sciences

This dissertation, written by Rafael Amiel-Saenz, and entitled Exchange Rate Overvaluation under Hyperinflation, having been approved in respect to style and intellectual content, is referred to you for judgement.

We have read this dissertation and recommend that it be approved:

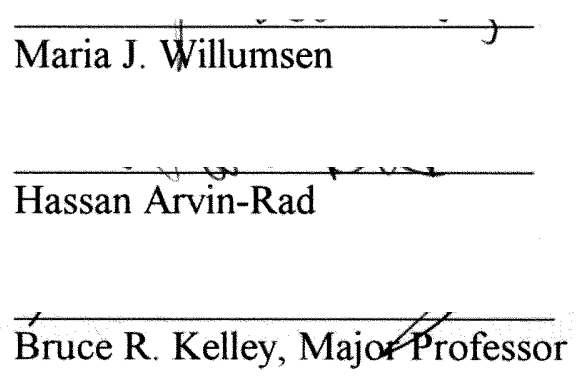

Date of Defense: November 22, 1996

This dissertation of Rafael Amiel-Saenz is approved.

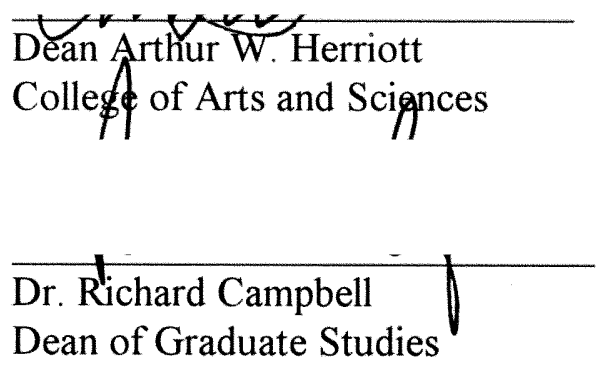

Florida International University, 1996 
I dedicate this dissertation to my parents. Without their patience, understanding, support, and most of all love, the completion of this work would not have been possible. 


\section{ACKNOWLEDGEMENTS}

I wish to thank the members of my committee for their helpful comments and patience. I also want to thank Mr. Carlos Moslares and Mr. Bala Veeramachenine for timely comments and help with editing; Manuel Carvajal for his support throught my staying at Florida International University.

A special thanks must go to my major professor, Dr. Bruce Kelley, for his support and encouraging comments, and especially for having the confidence in me to give me the chance to do this project. 


\section{ABSTRACT OF THE DISSERTATION \\ EXCHANGE RATE OVERVALUATION UNDER HYPERINFLATION: \\ THE CASE OF PERU}

by

Rafael Amiel-Saenz

Florida International University, 1996

Professor Bruce R. Kelley, Major Professor

This dissertation examines the behavior of the exchange rate under two different scenarios. The first one is characterized by, relatively, low inflation or a situation where prices adjust sluggishly. The second is a high inflation economy where prices respond very rapidly even to unanticipated shocks. In the first one, following a monetary expansion, the exchange rate overshoots, i.e the nominal exchange rate depreciates at a faster pace than the price level. Under high levels of inflation, prices change faster than the exchange rate so the exchange rate undershoots its long run equilibrium value.

The standard work in this area, Dornbusch (1976), explains the overshooting process in the context of perfect capital mobility and sluggish adjustment in the goods market. A monetary expansion will make the exchange rate increase beyond its long run equilibrium value. This dissertation expands on Dornbusch's model and provides an analysis of the exchange rate under conditions of currency substitution and price flexibility, characteristics of the Peruvian economy during the hyper inflation process that took place at the end of the 1980's. The results of the modified Dornbusch model reveal that, given a monetary expansion, the change in the price level will be larger than the change in the exchange rate if prices react more than proportionally to the monetary shock. 
We will expect this over-reaction in circumstances of high inflation when the velocity of money is increasing very rapidly. Increasing velocity of money, gives rise to a higher relative price variability which in turn contributes to the appearance of new financial (and also non-financial) instruments that report a higher return than the exchange rate, causing people to switch their demand for foreign exchange to this new assets. In the context of currency substitution, economic agents hoard and use foreign exchange as a store of value. The big decline in output originated by hyper inflation induces people to sell this hoarded money to finance current expenses, increasing the supply of foreign exchange in the market. Both, the decrease in demand and the increase in supply reduce the price of foreign exchange i.e. the real exchange rate. The findings mentioned above are tested using Peruvian data for the period January 1985--July 1990, the results of the econometric estimation confirm our findings in the theoretical model. 


\section{TABLE OF CONTENTS}

CHAPTER

PAGE

1. INTRODUCTION

A. Statement of the Problem ...................................................................

B. Importance of the Study ...................................................................

C. Existing Literature on Exchange Rate Determination............................... 7

D. The Peruvian Macroeconomy ........................................................... 11

The Heterodox Experiment and Hyper Inflation ................................... 13

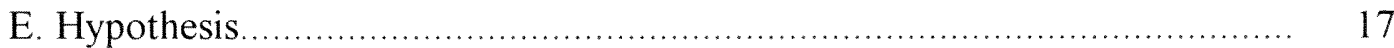

2. THEORETICAL AND EMPIRICAL BACKGROUND $\ldots \ldots \ldots \ldots \ldots \ldots \ldots \ldots . . . . . . . . .21$

2.1 Purchasing Power Parity (PPP) and Definition of Real Exchange Rate....... 21

2.1.1 Absolute Version of PPP …................................................. 22

2.1.2 Relative Version of PPP …................................................... 23

2.1.3 Definition of the Real Exchange rate …..................................... 26

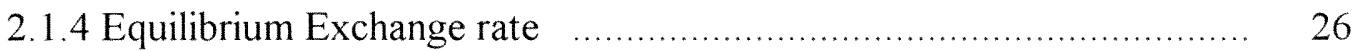

2.2. The Underlying Balance Approaches …......................................... 27

2.2.1 The FEER and the DEER ….............................................. 27

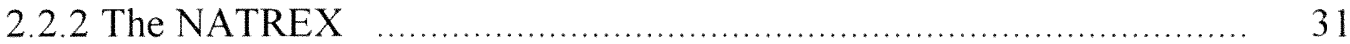

2.3 Asset Market Approaches to Exchange Rate Determination $\quad . . \ldots \ldots \ldots \ldots \ldots \ldots . . . . . .36$

2.3.1 The Monetary Approach to Exchange Rate Determination (MAER).... 36

2.3.1.1 Flexible Prices ............................................................ 36

2.3.1.2 Sticky Prices and the Real Interest Differential Monetary Model ... 38

2.3.2 The Portfolio Balance Model of Exchange Rate Determination .......... 39

2.4 Currency Substitution and Exchange Rates ........................................ 41 
2.6 Hyper inflation

3. THE MODEL

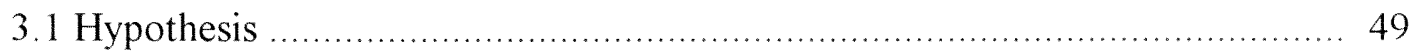

3.2 A model of Exchange Rate Determination .......................................... 52

3.2.1 Sticky Prices _..................................................................... 52

3.2.1.1 The Overshooting Process _................................................ 59

3.2.2 Flexible Output and Prices under Currency Substitution...................... 62

3.2.2.1 A monetary Expansion _........................................................... 69

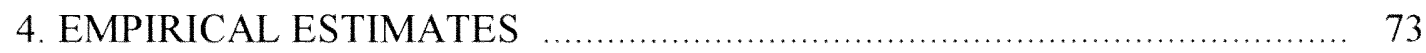

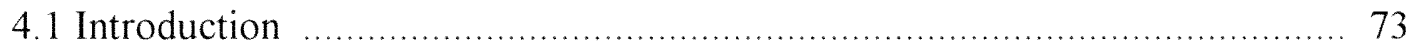

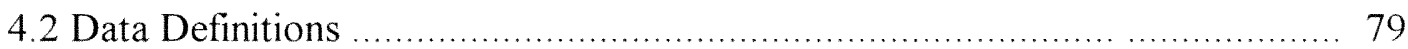

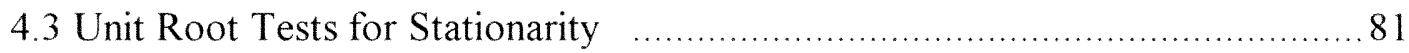

4.4 A Model on the Real Exchange Rate ..................................................... 84

4.5 On the Nominal Exchange Rate ......................................................... 91

4.5.1 An Instrumental Variable _........................................................ 95

4.5.2 Dropping the Domestic Interest Rate ............................................. 99

4.5.3 A Simultaneous Equation Model ….............................................. 101

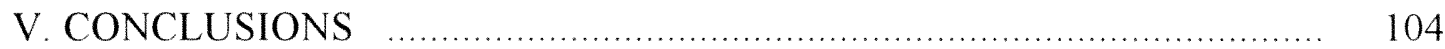

LIST OF REFERENCES _............................................................... 110 


\section{LIST OF TABLES}

PAGE

Table 1 Unit Root Tests on Levels ......................................................... 82

Table 2 Unit Root Tests on First Differences............................................... 83

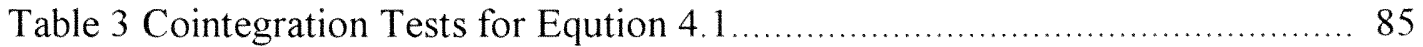

Table 4 Ordinary Least Squares Regression on Equation 4.1 .......................... 86

Table 5 Ordinary Least Squares Regression on Equation 4.1 1985-1988_............. 88

Table 6 Ordinary Least Squares Regression on Equation 4.1 1988-1990 ............ 89

Table 7 Cointegration Tests for Equation 4.2 .......................................... 92

Table 8 Ordinary Least Squares Regression on Equation 4.2 ........................ 93

Table 9 Cointegration Tests for Equation 4.3 .......................................... 96

Table 10 Ordinary Least Squares Regression on Equation 4.3 _........................ 97

Table 11 Cointegration Tests for Equation 4.5 ........................................ 99

Table 12 Ordinary Least Squares Regression on Equation 4.5 ..................... 100

Table 13 Cointegration Tests for Equation 4.6....................................... 102

Table 14 Two stage Least Square Regression for the System 4.6-4.7 _............. 102

\section{LIST OF FIGURES}

Figure 1.1 Inflation and the Real Exchange Rate ..................................... 2

Figure 2.1 Internal and External Balance ................................................ 29

Figure 3.1 Inflation and Depreciation ............................................. 51

Figure 3.2 Equilibrium in Goods and Asset Markets ............................. 57

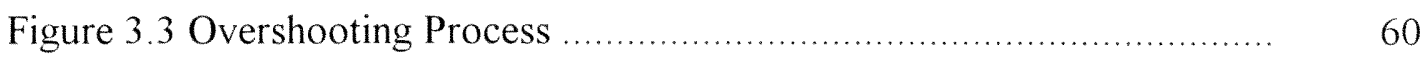

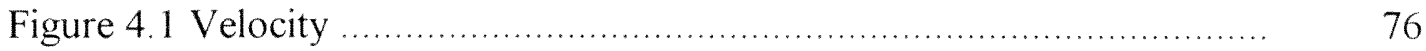




\section{CHAPTER 1}

\section{INTRODUCTION}

\section{A. Statement of the problem}

This dissertation examines the behavior of the exchange rate under two different scenarios. The first one is characterized by relatively low inflation or a situation where prices adjust sluggishly. The second is a high inflation economy where prices respond very rapidly even to unanticipated shocks. These two scenarios determine different paths in the evolution of the nominal and real exchange rate.

This study has been inspired by the hyper inflationary process that took place during the second half of 1980's in Peru. The Peruvian economy experienced, relatively, low levels of inflation from 1985 through 1987 and high levels of inflation during the period 1988-1990. When we observe the evolution of the real exchange rate we find that first, associated with low inflation, it depreciated and when inflation peaked the exchange rate exhibited real appreciation. (see Figure 1.1).

The main hypothesis of this dissertation states that when inflation is, relatively, low the exchange rate adjusts faster than domestic prices i.e. it depreciates in real terms. But when economic agents perceive a high, unusual, level of inflation the exchange rate appreciates. The first part of the hypothesis is what Dornbusch (1976) states in his seminal paper about exchange rate dynamics. He explains the overshooting process under the light of a sluggish adjustment in the good's market and an instantaneous clearing in the asset market. The adjustment process to a monetary expansion in this framework explains clearly the 
Figure 1.1
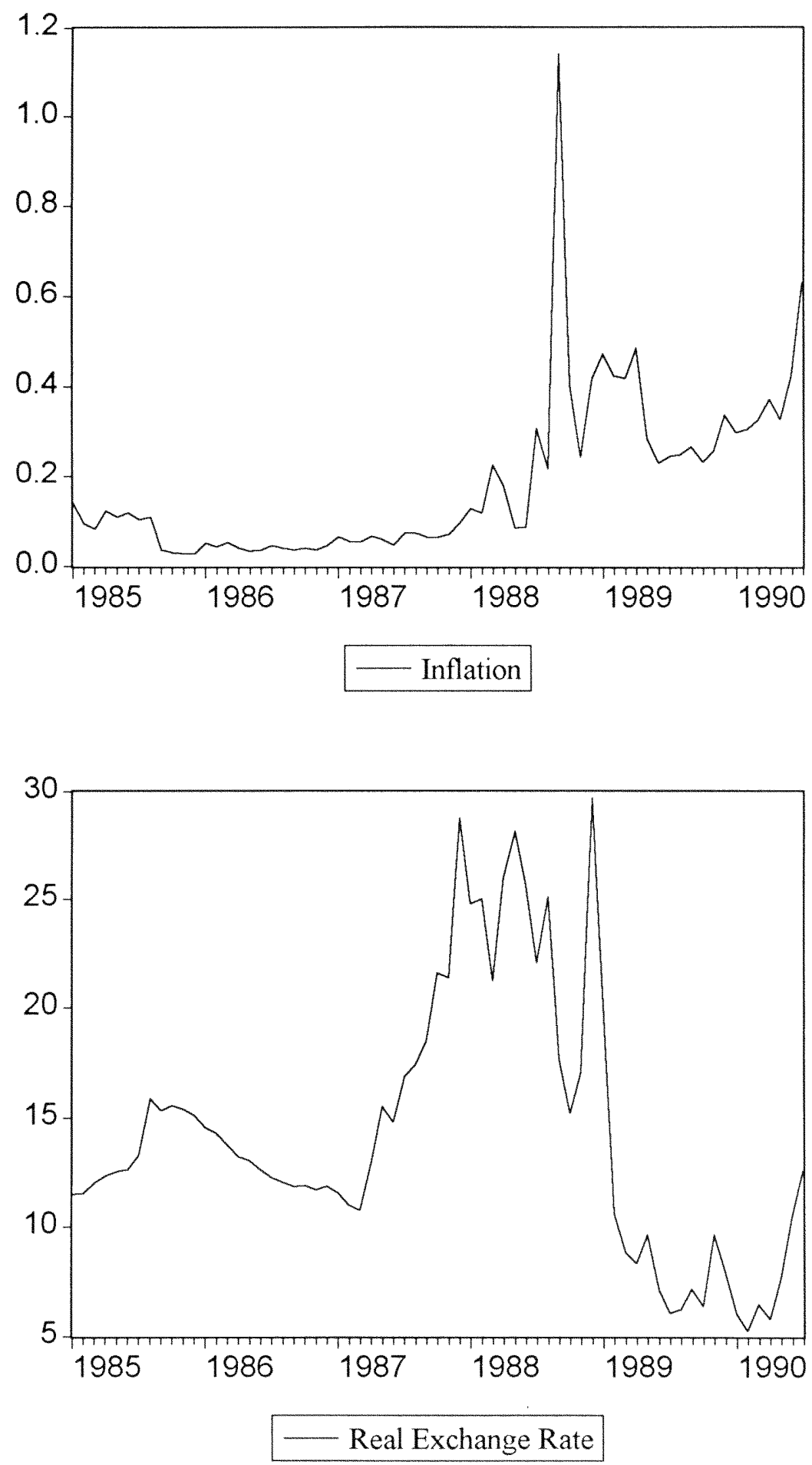
dynamics of the exchange rate. In the short run, a monetary expansion is shown to induce an immediate depreciation in the exchange rate and accounts, therefore, for fluctuations in the exchange rate and the terms of trade. Second during the adjustment process, rising prices may be accompanied by an appreciating exchange rate. In the long run, the increase in domestic prices will match the initial depreciation leaving the real exchange rate unchanged.

Dornbusch in his analysis assumes, first, that output is fixed in the short run and that there is perfect substitutability between domestic and foreign assets. It is also assumed that the country is small in the world capital market, thus it faces a given interest rate. Expected net yields are equalized through perfect capital mobility i.e. the domestic interest rate less the expected rate of depreciation will equal the world rate. Following this scenario the first assumption is relaxed leaving output free to change. In this way output responds, even in the short run, to any shock that may affect the economy.

I will expand Dornbusch model to determine the conditions under which the second part of the hypothesis --exchange rate overvaluation- holds. The main difference of my model with that of Dornbusch is that I relax the assumptions of sticky prices and fixed output and also discuss the stability of the coefficients incorporated in the money demand and aggregate demand functions. Later, I consider the case of currency substitution as opposite to perfect capital mobility. Peru experienced currency substitution during the hyper inflation period, the uncovered interest rate parity condition did not hold therefore perfect capital mobility did not take place. Currency substitution reflects economic and usually political instability of an economy, therefore it would be very unrealistic to assume that capital flows in and out of the country as a consequence of differences between domestic and foreign interest rates ignoring the significant role that risk plays. It is 
important to highlight that complete currency substitution did not take place in Peru during its hyper inflation period, had it been the case it would have been not misalignment of relative prices.

I will also relax the assumption of sticky prices in order to determine under what conditions the rate of domestic inflation is greater than the rate of depreciation of the exchange rate, hence inducing an overvaluation.

\section{B. Importance of the Study}

The exchange rate is one of the most important macro-prices in the economy. It is the link, in terms of prices, between the domestic economy and the rest of the world. It influences and is influenced by almost all relevant real and monetary variables that play a key role in any economic system. As a consequence exchange rate determination becomes a primary issue to be studied especially for policy makers.

The role of the exchange rate in inflation is controversial and critical. Two facts need to be highlighted. First, fixing the exchange rate when other prices of the economy are rising, guarantees progressive appreciation and probably overvaluation of the currency and difficulties in the balance of payments. Second, devaluation increases the prices of traded goods and is itself inflationary. Increases in the inflation rate are often precipitated by large devaluations.

In most of the countries that have experienced high rates of inflation, it has been observed that a real depreciation of the domestic currency is associated to it (inflation) and a process of real appreciation is related to the stabilization period, however it has not been 
exactly the case of Peru during the second half of the 1980's. As inflation grew from 1986 until July 1988 the Peruvian currency depreciated and became undervalued, but when inflation skyrocketed and turned to a hyper inflation process it started appreciating and ultimately became overvalued.

The purpose of this study is to identify the causes of this phenomena. It is very important to understand the underlying determinants of this situation, because when hyper inflation stops it leaves the country with serious problems, and if it follows that during the stabilization period the real exchange rate keeps appreciating the negative effects of it aggravate.

The main effects of overvaluations are:

- A loss in external competitiveness: This loss leads to an increase in imports and a reduction in exports. Even if the resulting trade deficit can be financed by reserves or borrowing, it may be unwise to give up these resources or to incur increased external liabilities that will ultimately need to be serviced by trade surpluses.

- Loss of domestic production, employment and fiscal revenues: Firms that can no longer profitably compete with imports or produce exports for the world market will cut production first, and if overvaluation persists, will stop production. The result will be a lost of jobs and tax revenue.

- Adverse effects on domestic financial markets: Traders will try to borrow in domestic currency to finance the buildup of imports or to carry stocks of exports that are held off pending devaluation. Interest rates will be pushed up and will hurt other sectors. If the overvaluation persists, many industries may go bankrupt speculating. If banks fail 
because of speculation, the government may have to incur heavy costs to avoid a collapse of the financial system.

One might think that, although all these things are possible in principle, they do not really occur. Not so, in fact the problems mentioned above took place in various forms in Chile, Argentina, Israel, Mexico and Peru (Dornbusch and Helmers 1988)

One of the main problems of inflation which aggravated during high inflation processes is the distortion of relative prices. (Di Tella 1979, Dornbusch and Helmers 1988, Patinkin 1993, among others) The exchange rate is a very important price and it is specially affected by hyperinflation, the effects on the whole economy are perverse whenever the rate of exchange is missaligned. Thus, it is important to study the conditions and causes of an exchange rate overvaluation or undervaluation.

The hyper-inflation process that took place in Bolivia, ended after the implementation of a stabilization program in which fixing the exchange rate was one of the key tools to stop inflation $^{1}$.(see Morales, 1990, in Bruno et. al.). A necessary condition to implement this policy, successfully, was complete dollarization (or a very high level of currency substitution). In most Latin American countries the exchange rate is defined only as the number of units of domestic currency paid for one US dollar. Complete dollarization occurs when all domestic prices (in an economy which is not the United States of America) are expressed in terms of dollars. Transactions may take place using domestic currency only after converting that price using the prevailing exchange rate. Prices expressed in dollars do not change, people believes that the purchasing power of the US dollar is constant, at least in the short run. 
Under complete dollarization, the most harmful characteristic of hyper-inflation, which is the misalignment of relative prices disappears and the solution is to set a nominal anchor: the exchange rate. This requires enough international reserves to guarantee the supply of foreign exchange at the fixed rate. In the case of Peru complete dollarization did not take place because there were not enough international reserves to back up the fixed rate. The exchange rate and the general price level did not change at the same pace, therefore relative prices were distorted. The real exchange rate appreciated and the consequences of overvaluation mentioned above took place after stabilization.

\section{Existing Literature on Exchange Rate Determination}

The history of the International Monetary System shows a pattern of shifts between a number of variants and combinations of fixed and flexible exchange rate regimes. In the late nineteenth century and up to 1914, the gold standard predominated in the international monetary system. A gold standard can be classified as a fixed exchange rate regime. When World War I started in 1914, the gold standard broke down. During the interwar years, the international monetary system experienced disarray, with the major industrial countries swinging between periods of flexible exchange rate regimes (as in the period 1919 to 1925 and from 1933 to 1934 ) and periods of return to the gold standard. In 1944 the so-called Bretton Woods system was implemented (dollar-gold standard), it was a fixed exchange rate regime and was in operation in the 1950's and 1960's. At the end of the decade of the 1960's Bretton Woods began to experience difficulties. It, finally, broke down in March 1973, were a system of flexible exchange rates took place in most of industrial countries. This situation opened an enormous field for researchers and theorists. Open macroeconomics and theory on exchange rate determination significantly enlarged the bulk of economic literature. 
Theory on exchange rate determination may be clustered into three major methodological approaches. First, the Purchasing Power Parity theory which determines the exchange rate from differences in domestic and foreign price levels. The second approach focuses on the "underlying balance" conditions for external and internal equilibrium. This approach considers the impact of the exchange rate on the real sector where the transmission mechanism is either the trade balance or domestic absorption. Finally, the asset market approach. It sees domestic and foreign currencies as substitutable assets where the exchange rate alters the relative price of these assets. The sticky-price monetary model of Dornbusch - also known as the overshooting model- has been classified within this category ( MacDonald and Taylor 1995).

A large number of authors have extended the overshooting model: among others, Frankel (1979), who argued that a shortcoming of the Dornbusch (1976) formulation of the sticky-price monetary model was that it did not allow a role for differences in secular rates of inflation. Frankel's model was an attempt to allow for this defect, and the upshot was an exchange rate equation that included the real interest rate differential as an explanatory variable. Buiter and Miller (1981) developed further Dornbusch (1976) formulation allowing for a non zero rate of core inflation and considered the impact of natural resource discoveries on output and the exchange rate.

Frenkel and Rodriguez (1982) relaxed the assumption of perfect asset substitutability and demonstrate that if asset substitution is relatively weak there may be an exchange rate undershoot in the initial period. Imperfect capital mobility precludes immediate adjustments in the asset market. Under this setting the exchange rate may become sticky relative to the domestic price level. Their model was consistent with Dornbusch. in the 
sense that setting the speed of adjustment of capital flows equal to infinity -i.e. perfect asset substitution- yields the same overshooting results.

The term real exchange rate overshooting was coined by Buiter and Miller (1982), although, it was already implied in Dornbusch model given the assumption of sticky prices. In Buiter and Miller's framework, real exchange rate overshooting is associated with the failure of the economy and the labor market in particular to adjust completely to unanticipated disturbances like an increase in money supply

Dornbusch model adopts the assumption that output is demand determined out of equilibrium. Driskill and McCaferty (1987) used a framework where domestic output demand and domestic output supply both depend on the relative price of domestic to foreign goods. Then, they assume that output is supply determined out of equilibrium. The results in both models are very close and therefore this assumption happens not to be crucial.

Lately, Obstfeld and Rogoff (1995) wrote a paper that incorporates the price rigidities essential to explain exchange rate behavior without sacrificing the insights of the inter temporal approach to current account. They developed a model of international policy transmission that embodies the main elements of the inter temporal approach along with short-run nominal price rigidities and explicit microfundations of aggregate supply. Their model predicts that money supply shocks can have real effects that last well beyond the time frame of any nominal rigidities, because of induced short-run wealth accumulation via the current account. 
The amount of research devoted to currency substitution, inflation and exchange rate variability is very large. It began with Calvo and Rodriguez (1977) and continued with Liviatan (1981), Calvo (1985), Engel (1989), Lee (1992), Calvo and Vegh (1993) and Heng-Fu Zou (1993) just to mention some of them.

Calvo and Rodriguez (1977) demonstrate in a model of a small economy in which residents hold foreign currency balances that an increase in domestic money growth will cause an immediate real depreciation of the currency. A higher rate of growth in the stock of money increases inflation in domestic currency prices, thus increasing the real demand for foreign money. The country can acquire this money only through a trade surplus, which requires the real depreciation. Liviatan (1981) provides a parallel model to Calvo and Rodriguez in which agents' behavior is optimal (rather than the described by ad hoc equations). Liviatan concludes that an increase in domestic money growth leads to a real appreciation domestically, and thus the Calvo-Rodriguez model is not correct in a model in which agents optimize. Engel (1989), demonstrates that the Calvo and Rodriguez results hold up in a utility maximizing model, contrary to the claim of Liviatan. It is argued that Liviatan conclusions are based on a mistaken assumption i.e. that the two monetary balances -domestic and foreign- are cooperant in utility. If the two moneys were nocooperant, a smaller amount of domestic currency holdings leads to a large marginal utility of liquidity services from the foreign currency. Zou (1993) approaches the problem of currency substitution in the same optimization model but adds the behavior of the government, he arrives at the same conclusion as Engel (1989), "if the government transfer its inflation tax to the public, dollarization will only happen when two currencies are non-cooperant in generating liquidity service". 
This dissertation contrasts to previous work in two main aspects: the first one relates to the fact that no one has considered hyper inflation and its associated relative price distortion as the qualitative source of exchange rate appreciation and ultimately overvaluation. Relatively low inflation does not imply a considerable misalignment of prices where agents change their portfolios rapidly and increase their propensity to consume. The second is the incorporation of currency substitution into Dornbusch framework and also the relaxation of the assumption of price rigidity for the short run. In the transition process between low and high inflation, dollarization arises. Economic agents use foreign currency to protect the value of their wealth, but when hyper inflation emerges distorting relative prices new instruments other than foreign exchange become more profitable and therefore more attractive as a store of value.

\section{The Peruvian Macroeconomy.}

Peru's modern history has been marked by political and economic instability. Single-term democratically elected governments have usually been followed by periods of military juntas and vice versa, in an almost alternating sequence. In turn, recurrent expansionary macroeconomic policies have ultimately run into foreign exchange crises and subsequent stabilization episodes. The Peru of the 1950's has been characterized as a laissez-faire economy. The economy was open to foreign trade; export of raw minerals, mostly exploited by foreign interests, and fish meal paid for imported manufactures. In turn, the government had little direct participation in the economy, and economic activities were largely unregulated. Industrialization by import substitution and government spending in the infrastructure started with the first government of Fernando Belaunde (1963-1968). A long-pursued tax reform needed to restore macroeconomic stability was systematically 
opposed by an uncooperative Congress, and Belaunde's first term ended with an economic crisis and a military coup.

During the nationalistic rule of General Velasco Alvarado (1968-1975), the government embarked on an inward-looking growth strategy, established a broad array of controls on economic activity, nationalized foreign corporations -particularly mining and hydrocarbons- gave workers participation in ownership and management of private firms, and undertook a global agrarian reform. Large-scale public investment project and a rapidly growing state enterprise sector brought about a mounting foreign debt.

Favorable external conditions during 1970-1974 allowed rapid expansion of employment and incomes. In fact, real income per capita had growth steadily, at an average annual rate of about 2.7 percent, during the entire 1950-1974 period, with the exception of 19681969. In parallel, inflation during that period had been moderate but growing. It rose from annual average of 7 percent in the 1950's to the teens in the 1960's and early 1970's.

Starting in 1974, a deep downswing in the terms of trade together with a sudden withdrawal of foreign financing sources, in the wake of overly expansionary fiscal spending, set the ground for a long recession (Lagos 1991). In that process, General Velasco Alvarado was forced out of office in 1975 by an internal coup that put his prime minister, General Morales Bernudez, into the presidency. Income per capita stagnated in 1974-1976 and then dropped for two consecutive years 1977-1978 by a cumulative 5 percent, while inflation accelerated from single digit rates early in the decade to nearly 70 percent in 1978 . 
A strong stabilization attempt was initiated in 1978-1979, with the help of favorable terms of trade. In 1980, confident that economic growth had resumed and international reserves had been restored, the government initiated an import liberalization program. In that year, general elections were held and Fernando Belaunde was voted back into the presidency. Belaunde enjoyed massive international support but inherited a country with overwhelming social problems, an income per capita below its 1974 level, and major economic distortions. However, during its first three years his government engaged in expansionary fiscal and monetary policies, which caused inflation to double to 100-plus percent in 1983. Subsequently, the foreign trade liberalization process was reversed. Likewise, the parceling out of land plots that had been granted to cooperatives by military rulers was effected in a less than orderly fashion. In 1983, after frustrated negotiations on foreign debt rescheduling and fresh financing with commercial creditors, the government switched into a policy of "undeclared" arrears. In its last two years (1984-1985), the Belaunde administration engaged in a serious effort to stabilize the economy. Public-sector prices were raised significantly and an aggressive exchange rate policy was pursued. The Central Bank took an independent position from the executive and forced the later to effect expenditure cuts and seek genuine sources of revenues.

\section{The Heterodox Experiment and Hyper Inflation}

At the time Alan Garcia was sworn in as president in July 1985, Peru's income per capita was comparable to what it had been in the late sixties, more than half of the labor force was registered by official statistics as not properly employed and inflation was nearing 200 percent in the 12 month period ending in August 1985. Although the official creed of the second Belaunde administration (1980-1985) had been orthodox public finance and free markets, it undertook during its first three years ambitious infrastructure investments that 
required inflationary financing. Macroeconomic imbalances were compounded by the international recession, the drying up of voluntary external financing due to the onset of the debt crisis in 1982, and a severe natural disaster in 1983, when "El Nino" caused floods in the north and droughts in the south. These factors materialized in a 13 percent decline in GDP per capita in 1983-1985.

Against this economic background, the sociopolitical situation had quickly deteriorated with continuos labor strikes and frequent attacks by Peru's two terrorist movements (the sierra-based Maoist Sendero Luminoso, a Shining Path, and the urban, Cuban style guerrilla group, MRTA). A further complication was constituted by the flourishing of drug cropping in the Upper Huallaga Valley where cocaine growers had reached a corrupted symbiosis. Sendero provided cocaine growers with protection against the government and, in return, the growers provided Sendero with finance resources. During this period, export revenues from drug exports have been conservatively estimated at $\$ 1$ billion per year or about 4 percent of GDP ( Abusada 1987).

As it has been said, the last two years of Belaunde's term (1984-1985) were marked for a moderated discipline in fiscal expenditures and also an exchange rate policy oriented to improve international competitiveness of exports. This policy course left a good legacy to the incoming APRA government in terms of a competitive exchange rate, high public sector prices, and a relatively strong international reserve position.

These initial conditions, which characterized the end of a recessionary phase in Latin America's chronic stop-and-go economic policy cycles, provided one of the basic premises, as stated in Dornbusch and Edwards (1990) and Sachs (1989), for short-lived consumption-led boom. The other basic premise is, of course, a poverty stricken country 
with restless and rising social and political conflicts, of which Peru is a good example. An additional ingredient for a populist course was suitably offered by the pre-existence of an incipient and undeclared policy of external arrears, which had been initiated by the Belaunde administration in late 1983. At the time of the changeover of administrations, external arrears on Peru's then- $\$ 14$ billion debt had surpassed $\$ 2$ billion. The preexistence of the facto arrears also provided a convenient departure point for a policy of confrontation with Peru's creditors.

In examining the heterodox package, five major elements can be identified. The first four involve short-term goals: price stabilization, economic reactivation, income redistribution and lower debt repayment while the last element involves the transition to medium term growth. What made the plan intrepid was that in most cases the specific policies directly contradicted the orthodox approach that was recommended to Peru over the past decade. For example, inflation was attacked directly by fixing key prices, mainly the exchange rate, interest rate and prices of many basic goods rather than indirectly via manipulating the money supply. In addition private consumption and government demand, rather than exports and investment, were the cardinal drivers behind the initial recovery. Finally real wages increased rather than decreased, which solidified political support while sparking further consumption and growth.

This program was a good attempt as an stabilization program but, obviously, it only last up to the point where the source of funding price controls was exhausted i.e. International Reserves. At the beginning of the heterodox program, before fixing prices, the official exchange rate was devaluated. This operation further depreciated the exchange rate (if the official exchange rate is larger than its PPP value, consequently the so-called parallel or free market exchange rate is also over the parity). This procedure was followed with some 
other prices, allowing the government to freeze them for a certain period of time. This intrepid program started collapsing at the end of 1987 when International Reserves were almost depleted. The rebound in economic activity produced a rapidly tightening external constraint. Economic reactivation and fixed exchange rate produced a $\$ 800$ million surge in imports in 1986, up over 43 percent in dollar terms. In percent terms the increase was fairly uniform across sources of demand with the largest absolute increase recorded by intermediate demand where imports rose by $\$ 400$ million. At the same time exports were falling, down $\$ 450$ million or 15 percent in 1986 .

These trends concerning imports and exports are clearly reflected in the trade and current account balance. In 1985, due to the depressed level of domestic demand, Peru recorded its third consecutive trade surplus with exports exceeding imports by $\$ 1.1$ billion. In 1986 this surplus disappeared, and the country incurred in a small deficit. This trend continued in 1987 when the trade deficit amounted $\$ 500$ million. The deterioration of the current account was more rapid. A small surplus in 1985 was replaced by a $\$ 1.1$ billion deficit in 1986 and a 1.6 billion in 1987 . The country lost over $\$ 500$ million in international reserves in 1986 and $\$ 780$ million in 1987 . Net reserves were only $\$ 80$ million at year end (Kelley 1996).

The implementation and then a further expansion of a multiple exchange rate and import license system and a series of small devaluations, were the policies used to face the external bottleneck problem. As monthly inflation rose from 6 percent to 10 percent, these mini-devaluations did little to reverse the real appreciation of the official exchange rate. As inflation kept increasing and public confidence vacillated the black-market exchange rate premium jumped as the public began hoarding dollars. 
The populist experiment revealed its inadequacy beginning in 1988, three major one-shot economic packages were implemented during 1988. In the three cases the measures finally announced had undergone a tough political filter. The three of them were very similar. Namely they established adjustments in public prices, exchange rates, interest rates, and wages. In addition, the first two included a follow-up 120-day freeze on prices, wages and the exchange rate. Meanwhile, the parallel exchange rate was following market forces and surely was much higher than the official. and overvalued i.e. the domestic currency experienced a real depreciation.

By late 1988, the economy had taken off on a hyper inflationary path, with inflation accelerating from an annual rate of 360 percent in the first half to nearly 7,000 percent in the second half, and real money falling to one third of its level one year earlier. Economic agents had interpreted the government's corrective attempts as destabilizing, leading first to a massive rush to the dollar and then to other assets with the capacity to serve as store of value. Hyper recession walked hand in hand with hyper inflation, GDP decline by 8.8 percent in 1988 and dropped by 10.4 percent in 1989. The recession was prompted by the collapse of private investment -brought about by the unstable inflationary trend- and also by the downfall of public-sector real aggregate demand. The economic policy during 1989 and the first half of 1990 engaged in an erratic sequence of ad hoc measures driven by short run developments. In general, measures followed a "zigzag" pattern with later measures running in opposite direction to earlier ones in an attempt to correct their destabilizing effects. Along with hyper inflation and hyper recession, the free market exchange rate started appreciating as people began using their hoarded dollars to purchase goods and basic foodstuff, and speculators switched from dollars to more attractive financial assets and also to commodities which price level skyrocketed faster than the dollar. 


\section{E. Hypothesis}

A monetary expansion leads to the overshooting process described in Chapter 3 of this dissertation, prices in the good's market adjust sluggishly relative to asset prices. The main hypothesis of this study is that overshooting takes place only under, relatively or usual, low levels of inflation. When inflation increases in such a way that it is not only a higher figure but it characteristics determine a big distortion of relative prices and the economy engages in a hyper inflationary process -always associated with monetary expansions- the real exchange rate appreciates and ultimately becomes overvalued ( here I use Dornbusch's jargon, what becomes overvalued is domestic currency).

Real exchange rate depreciation, is supported by Dornbusch's overshooting model. In order to prove the hypothesis I extend Dornbusch's model relaxing the assumption of sticky prices and considering currency substitution instead of perfect capital mobility. The model yields the following conclusions:

1) exchange rate overshooting and undershooting is explained by analyzing the properties of the coefficients of the aggregate demand and money demand functions under the two different scenarios (low inflation and high inflation). Basically I discuss the consumption behavior of agents analyzing the marginal propensity to consume, income elasticity of money demand and the sensitivity of aggregate demand to changes in relative prices When inflation accelerates so does the marginal propensity to consume, this will increase aggregate demand and impose upward pressure on the domestic price level. Money burns in the hand of people and as soon as they receive their wages, they buy in advance commodities (most of them non-tradable) using them as store of value. 
2) "a monetary shock will cause the price level to adjust faster than the exchange rate if prices grow more than proportionally to the increase in the money stock" In the light of the quantity equation this condition arises when the income velocity of money increases and/or when output decreases. This two conditions are precisely those associated with very high inflation levels or hyper inflationary economies, and this is exactly what happened in Peru during its hyper inflation period (1988 -1990).

Due to the fact that high inflation levels, associated with a higher velocity of money, distort the relative price structure in such a way that new -more profitable- financial (and also non-financial ) instruments appear in the market, we expect that people turn aside their demand for foreign exchange towards the "new" more profitable assets. A lower demand for foreign exchange leads to an appreciation of the exchange rate.

The remaining of this dissertation is organized as follows, Chapter 2 is a literature review. It deals with the three main approaches to exchange rate determination: First Purchasing Power Parity theory, then the Underlying Balance Approach and finally the Asset Market Approach. A survey on currency substitution is also included and a review of the related empirical work.

Chapter 3, starts with the original model by Dornbusch (1976), with sticky prices, perfect capital mobility and fixed output. Then output is allowed to vary and finally, perfect capital mobility is replaced by currency substitution and prices become flexible even in the short run.

Chapter 4 consists of the empirical evidence. The model derived in Chapter 3 is estimated for Peruvian data ranging from January 1985 to July 1990. The conclusions found in the 
previous chapter are examined and discussed in these circumstances. The econometrics in this chapter include unit root for stationarity and cointegration tests, this techniques become particularly important given that all variables become very volatile under a context of hyper inflation. For econometric purposes it is required that all variables involved in the model be stationary. If not, statistical inferences become invalid unless the variables are cointegrated. Finally, Chapter 5 summarizes the conclusions and findings of this dissertation.

\section{Notes}

1.- Exchange rate unification was supported domestically by tight monetary and fiscal policies and externally by a significant reduction in the debt. 


\section{CHAPTER 2}

\section{THEORETICAL AND EMPIRICAL BACKGROUND}

At least three major methodological approaches to analyzing the real exchange rate can be identify. First, the Purchasing Power Parity theory which determines the exchange rate from differences in domestic and foreign price levels. The second approach focuses on the "underlying balance" conditions for external and internal equilibrium. This approach considers the impact of the exchange rate on the real sector where the transmission mechanism is either the trade balance or domestic absorption. Finally, the asset market approach. It sees domestic and foreign currencies as substitutable assets where the exchange rate alters the relative price of these assets.

\subsection{PURCHASING POWER PARITY (PPP) AND DEFINITION OF REAL EXCHANGE RATE}

Purchasing Power Parity is, in essence, a theory of exchange rate determination. It states (in the most common form) that the exchange rate between two currencies over any period of time is determined by the change of the two countries' relative price levels. It has been also called the "inflation theory of exchange rates" because it identifies price levels, as the only determinants of exchange rates movements.

Purchasing power parity remains an essential element of open macroeconomics because it is a bench-mark by which to judge the level of an exchange rate. Gustav Cassel (1928) argued that without PPP, there would be no meaningful way of discussing over or undervaluation. 


\subsubsection{Absolute Version of PPP}

Let $p_{i}$ and represent the price of the ith commodity at the domestic country expressed in domestic currency. Let, also, $p^{*}{ }_{i}$ represent the price of the ith commodity at the foreign country expressed in the foreign currency. The exchange rate, $e$, is the number of units of domestic currency per unit of foreign money.

The strong or absolute version of PPP relies on the law of one price in an integrated, competitive market. Abstracting from all and any friction the price of a given good will be the same in all locations when quoted in the same currency. Arbitrage guaranties:

$$
p_{i}=e p_{i}^{*}
$$

Thus, if for some reason the left hand side of (2.1) is greater than the right hand side, it would be profitable to ship the good from the foreign country to the domestic country, thereby forcing the domestic currency value of the foreign good up (by a rise in e and/or $\left.p^{*}{ }_{i}\right)$ and the domestic price of the good go down, until the equality of the two goods is reached again.

Consider now a domestic price index $P=f\left(p_{l}, \ldots, p_{i}, \ldots, p_{n}\right)$ and a foreign price index $P^{*}-$ $g\left(p^{*}{ }_{1}, \ldots, p^{*}{ }_{i}, \ldots, p^{*}{ }_{n}\right)$. If the prices of each good, expressed in the domestic currency, are equalized across countries, and if the same goods enter each country's market basket with the same weights, then the absolute PPP prevails. The law of one price in this special case extends not only to individual goods but also to aggregate price levels.

$$
e=\frac{P}{P^{*}}
$$


Recall that $P$ and $P^{*}$ are the price levels at home and abroad quoted in the respective currencies. Whatever the monetary or real disturbances in the economy, because of instantaneous, costless arbitrage, the prices of a common basket of goods in the two

countries, measured in a common currency will be the same or: $\frac{P}{e P^{*}}=1$, will hold always

(i.e. the law of one price).

The strong assumptions on which equation (2.2) relies make it very restrictive. Even if it were possible to construct price indexes in the way they were defined above, the existence of transportation costs and other impediments to trade, such as tariffs and quotas, will prevent conditions (2.1) and (2.2) from holding exactly. The fact that prices of homogeneous goods are not equalized across space at every point in time does not suggest market failure, it may simply reflect the inability to shift commodities costlessly and instantaneously from one location to the other.

\subsubsection{Relative Version of PPP}

The weak or relative version of PPP restates the theory in terms of changes in relative price levels and the exchange rate: $e=a P / P^{*}$, where $a$ is a constant reflecting the given obstacles to trade. Given these obstacles, an increase in the home price level relative to that abroad implies an equally proportional depreciation of the home currency: Or, in other words, the percentage exchange rate depreciation is equal to the difference between domestic and foreign inflation.

$$
\Delta e=\Delta P-\Delta P^{*},
$$

where $\Delta$ denotes a percentage change. 
From equation (2.3), a definition of the change in the real exchange rate may be produced, assuming PPP holds, the real exchange rate change should be zero.

Often a proponent of PPP is understood as someone who believes that expressions as (2.2) and (2.3) hold continuously at all times. However, it is clear from the writings of Cassel (1918), and other prominent proponents of PPP, that the concept is often taken to be the level around which an exchange rate oscillates.

Absolute PPP in (2.2) was stated in terms of the relative prices in different currencies and locations of a given and common basket of identical goods. Going from there to relative PPP as in (2.3) may merely be a way of circumventing the qualifications arising from transport costs or obstacles to trade. But often more is involved because the shift, in practice, leads to a use of PPP in terms of particular indexes such as CPIs, WPIs or GDP deflators. Once that is done, we go beyond the law of one price because the shares of various goods in the different national indexes may not be the same and the goods that enter the respective indexes may not be strictly identical as is clearly the case for non traded goods.

Once shares in the indexes are no longer equal and commodities are not strictly identical, the appeal to the law of one price can no longer serve as support for PPP. Now PPP can only hold, even in the weak form, if the conditions of the homogeneity postulate of monetary theory are justified.

The homogeneity postulate asserts that a purely monetary disturbance, leaving unchanged all equilibrium relative prices, will lead to an equally proportional change in money and all prices, including the price of foreign exchange. In this special experiment PPP holds even 
if the law of one price does not apply. The constancy of real variables under that assumption of a purely monetary disturbance (i.e., an anticipated, non recurrent increase in money) ensures that once the economy has adjusted, the exchange depreciation matches the inflation rate of any individual price or the price of any market basket so that (2.3) applies. According to Dornbusch (1988) PPP theory as a theory of equilibrium must be supplemented by an adjustment mechanism. In the case of identical commodities the theory is simply that of spatial arbitrage. But when the goods are not strictly identical, more is required. A high degree of substitution in world trade is generally assumed to be the mechanism through which exchange rate adjusted prices are kept in line internationally. A further point concerns causation. In much of the literature, especially in Cassel, exchange rates adjust to prices. But there is an important alternative tradition that singles out exchange rate depreciation as an independent source of inflation. MacDonald (1995) asserts that in circumstances in which there are short-run real exchange rate changes, it is possible for causation to run from exchange rates to prices. For example, consider the situation in which from a position of absolute PPP holding there is a one-shot capital outflow from the domestic country, thereby depreciating the nominal rate and, with sticky prices in the short run, the real rate.

In Chapter 3, I build up on Dornbusch (1976) model which assumes sticky prices, so the exchange rate adjust first, in my model I allow for both, the price level and the exchange rate to change at the same time. In the context of hyper inflation relative prices of tradable with respect to non-tradable are important but the most important feature of the exchange rate is to determine the capability of foreign exchange to serve as store of value. In this matter it competes with some consumption goods which, under high inflation rates, become very profitable. 


\subsubsection{Definition of the real Exchange Rate}

In order to be able to talk about a real exchange rate appreciation, a real depreciation, an overvalued currency or an undervalued one, it is necessary to define explicitly the real exchange rate.

The definition of real exchange rate that follows from PPP theory is:

$$
e_{t}=\frac{E_{t} P_{t}^{*}}{P_{t}}
$$

$e_{t}=$ Real exchange rate at time $\mathrm{t}$

$E_{t}=$ Nominal exchange rate at time $\mathrm{t}$. The nominal exchange rate is defined as the number of units of domestic currency paid for one unit of foreign currency.

$P_{t}{ }^{*}=$ world price index

$P_{t}=$ domestic price index

If PPP holds $e_{t}$ does not change over time. A real appreciation will take place when $e_{t}$ decreases, a real depreciation occurs when $e_{t}$ goes up. In the later case we say that the capacity to buy foreign goods (purchasing power abroad) of the domestic currency has fallen. The inverse situation will happen in the case of an appreciation.

\subsubsection{Equilibrium Exchange Rate}

Fluctuations in real exchange rates are often treated as temporary deviations from the "long-run" equilibrium exchange rate, for which purchasing power parity remains the prevailing paradigm. Moving from the absolute version of the PPP to the relative one, 
implies a search for the exchange rate that precludes any kind of arbitrage across countries. This may be interpreted as a first definition of equilibrium exchange rate

Besides PPP there are two other approaches for equilibrium exchange rate determination: the "underlying balance" approach, and those based on structural exchange rate models such as the monetary model or the portfolio balance model of exchange rate determination.

\subsection{THE UNDERLYING BALANCE APPROACHES}

This section provides a discussion of exchange rate determination focusing on events that take place in the real sector. In a period of hyper inflation, monetary events clearly dominate those in the real sector, hence underlying balance approaches do not fit accurately high inflation processes

\subsubsection{The FEER and the DEER.}

The underlying balance approach to the equilibrium exchange rate was developed by the International Monetary Fund (IMF) staff during the 1970s (see Artus 1977 and IMF 1984). More recently, the equilibrium rate associated with underlying balance has been named the "fundamental equilibrium exchange rate" (FEER) by Williamson (1985). The concept of "fundamental" equilibrium would be more applicable to a long-term situation where all underlying economic forces had worked themselves out, in particular where actual assets stocks are at their desired levels. A slightly different approach is the "desired equilibrium exchange rate" (DEER) where the concept of equilibrium exchange rate consistent with underlying macroeconomic balance is based upon a set of desired 
macroeconomic objectives. This terminology is not meant to imply that the calculated equilibrium exchange rate is desired in and of itself, but rather that is consistent with, and necessary for, achieving "desired" positions of internal and external balance. DEER should not be viewed as an ultimate target itself, but rather as facilitating the achievement of macroeconomic objectives.

The DEER is defined as the real effective exchange rate at which an economy is in both internal an external macroeconomic balance in the medium term. The medium term in this context means the period needed for output to return to potential and for changes in competitiveness to be reflected in trade volumes, which would appear to be in the range of four to six years. External equilibrium is defined in terms of a sustainable value of the current account balance. Internal balance is usually defined as potential full-employment output, in most computations (e.g. those of Williamson 1985 and 1991) this is computed independently and therefore does not depend on the real exchange rate. Under this assumption the DEER associated with internal and external balance is illustrated in Figure 2.1, where full employment income $\mathrm{Y}^{*}$ is drawn as a vertical line in real exchange rate (e) and real income $(\mathrm{Y})$ space. The current account $(\mathrm{CA})$ schedule is drawn for a given level of the current account balance and, assuming the well-known Marshall-Lerner condition holds (net import propensity) slopes downward from left to right; as real income increases, (net) imports tend to rise, requiring a devaluation of the real exchange rate to maintain an unchanged current account position. The solutions for $e^{*}$ and $\mathrm{Y}^{*}$ give the DEER and the internal balance position. 
Figure 2.1 Internal and external Balance

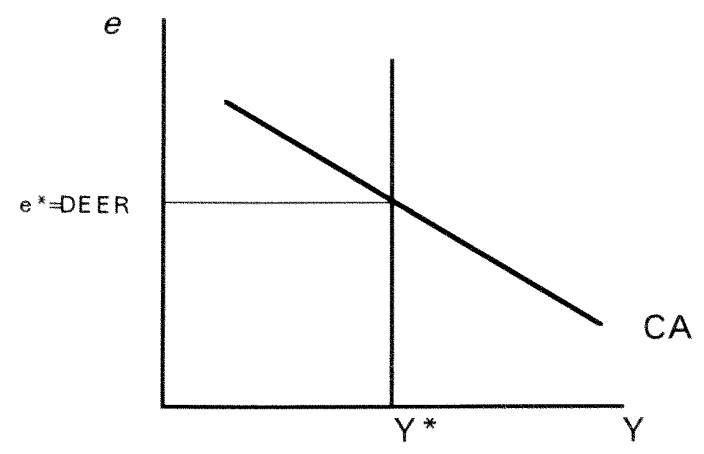

One important issue is how to define the sustainable level of the current account. One approach, is to calculate it from the difference between desired levels of saving and investment. Williamson notes that, as the current account is a flow variable, representing the rate of international lending or borrowing of an economy, one needs to examine whether a given current account position is likely to lead to an unsustainable debt buildup in the medium term. This suggest that the desired level of the current account could be approached by considering the underlying stock equilibrium for international assets. Once this equilibrium has been identified, the desired path for the current account would depend both upon the underlying equilibrium level of net foreign assets for the economy in question and upon the adjustment path toward this equilibrium. This desired path for the current account could then be used to identify the appropriate DEER trajectory.

Although Williamson has generally used large macroeconomic models to calculate DEERs, it is basically a comparative static, partial equilibrium calculation, as noted by Wren-Lewis (1992). Given values of the desired levels of output and the current account, the DEER is the level of the real effective exchange rate consistent with achieving these goals in the medium term. If we denote with asterisks the levels of domestic income (Y), foreign income (FY), and the current account (CA) that correspond to internal and 
external balance, the DEER is then $e^{*}$, the value of the real exchange rate $e$ derived from equation (2.5):

$$
\mathrm{CA}^{*}=\mathrm{CA}\left(\mathrm{Y}^{*}, \mathrm{FY}^{*}, e^{*}\right)
$$

The easiest method of calculating the DEER is to start from the values of Y, FY, CA and $e$ in the current (i.e. base) period and then compute the change in $e$ implied in moving $\mathrm{Y}$ to $\mathrm{Y}^{*}, \mathrm{FY}$ to $\mathrm{FY}^{*}$, and $\mathrm{CA}$ to $\mathrm{CA}^{*}$ using the following function:

$$
\mathrm{CA}=\mathrm{CA}(\mathrm{Y}, \mathrm{FY}, e)
$$

Although there appear to be three targets and only one instrument, it is assumed that $Y$ and $\mathrm{FY}$ move to $\mathrm{Y}^{*}$ and $\mathrm{FY}^{*}$, respectively, through the natural operation of economic forces, so that there is in effect one instrument, $e$, to achieve $\mathrm{CA}^{*}$.

The three elasticities required to make equation (2.5) operational are the sensitivities of the current account to domestic activity, foreign activity and the real exchange rate, which can be derived from estimated trade equations.

One feature of the exercise outlined above is that fiscal policy has no explicit role in the calculation. This may appear surprising at first sight, but there can be reasons for taking the view that fiscal policy has little independent effect on the DEER for given levels of $\mathrm{Y}^{*}$, $\mathrm{FY}^{*}$, and $\mathrm{CA}^{*}$. Of course, fiscal policy affects the current account in the short run through two main channels -changes in the exchange rate movements and the movements in the output relative to potential- and both of these channels are taken into account in the calculation of the DEER. But it does not say that fiscal policy cannot have an independent 
impact on the DEER. Fiscal policy can have a direct impact on the current account (and hence the DEER) over and above its indirect effects through aggregate demand. For example, if government consumption has a different import multiplier from other domestic spending, or if changes in fiscal policy affect the level of potential output, then it would be appropriate to include a separate effect of fiscal policy on the DEER.

The comparative static, partial-equilibrium approach has certain advantages and disadvantages. On the positive side, the calculations are simple and transparent-features that also make it easy to test the sensitivity of the calculations to alternative assumptions. On the other hand, certain dynamic factors are inevitably ignored. As noted above, this approach assumes that the current account in the base period has fully adjusted to past changes in output and the real exchange rate. In addition, it ignores the impact on the DEER of the path to equilibrium. For example, continuing current account imbalances may imply a significant change in the level of net external assets, which in turn feeds back onto the net flows of interest, dividends, and profits. Moreover, policies that affect the level of investment will change the level of potential output and hence the medium-term level of activity. Finally, the comparative static, partial-equilibrium approach abstracts from considerations relating to asset market equilibrium and therefore it assumes that interest rates are always at their equilibrium levels. As it has been said in the introduction this section is included just for the sake of completeness.

\subsubsection{The NATREX}

Another version of the "underlying balance" approach to exchange rate determination is the so called NATREX that stands for NATural Real EXchange, it refers to a medium run, inter-cyclical equilibrium real exchange rate, determined by real, fundamental factors. 
It is important to highlight the fact that the NATREX is a moving equilibrium real exchange rate, that responds to changes in exogenous and endogenous real fundamentals. In a world of high capital mobility, the fundamentals of thrift, productivity, capital intensity, and net debt to foreigners become particularly important, influencing desired long-term capital flows and modifying the equilibrium real exchange rate

The NATREX is the equilibrium exchange rate that clears the balance of payments in the absence of cyclical factors, speculative capital flows, and movements in international reserves. The NATREX approach always describes equilibrium situations, it avoids the problems of modeling speculative flows and cyclical factors. A NATREX model starts at some hypothetical inter-cyclical medium run, in which prices have adjusted and output has returned to its inter cyclical potential level. The real exchange rate has adjusted to its current equilibrium level. Demand for money equals supply of it, with no foreign exchange intervention by the central banks. This medium run equilibrium that is the long run equilibrium of most monetary models is the starting point of a NATREX model.

The medium run market-clearing equilibrium of a NATREX model can be described by the national income account equation

$$
I-S+C A=0
$$

where $I$ is desired national investment, $S$ is desired national saving, and $C A$ is desired current account, all measured when the economy is at capacity output and expectations about inflation are met. The real exchange rate, $e$, appreciates in response to an excess demand for goods, in such a way that equilibrium is always reached.

Equation (2.6) can be read as both equilibrium in the balance of payments and equilibrium in the good's market. Desired investment minus desired savings, I-S, always describes the sum of the country's excess flow supplies of financial assets (FA) 
$\mathrm{FA}=\mathrm{X}_{\mathrm{N}}+\mathrm{X}_{\mathrm{L}}+\mathrm{X}_{\mathrm{S}}+\mathrm{X}_{\mathrm{M}}$

where $X_{N}=$ non-tradable securities

$$
\begin{aligned}
& X_{L}=\text { tradable long term securities } \\
& X_{S}=\text { tradable short term speculative securities } \\
& X_{M}=\text { domestic money }
\end{aligned}
$$

Given the medium-run conditions that:
a) the domestic securities market clear, $X_{N}=0$
b) short term speculative capital flows cancel out, $X_{S}=0$
c) money equilibrium prevails with no official foreign-exchange intervention, $X_{M}=0$,

any difference between investment and savings represents the excess flow supply of tradable long term securities: I $-\mathrm{S}=\mathrm{XL}$. Under these conditions, $\mathrm{I}-\mathrm{S}$ describes desired net long term capital inflows, and equation (2.6) is the sum of the current and capital accounts, or balance-of-payments equilibrium. The equilibrium real exchange, $R$, simultaneously clears the goods market and assures balance-of-payments equilibrium.

In the clearing of the market, the current account responds to changes in R. Desired saving and desired investment are assumed to be either independent of the real exchange rate or relatively unresponsive to it, compared to the responses of the current account. This assumption simplifies the NATREX models and has implications for the trajectory of the real exchange rate, but is not crucial to the NATREX approach. Desired investment and saving, relatively independent of the real exchange rate, depend on the existing stocks of capital, wealth, and net debt to foreigners. When these stocks are changing, the NATREX, an equilibrium exchange rate, becomes a moving equilibrium. NATREX models focus on the results of investment, saving, and net capital flows overtime. Investment $(I)$ and saving $(S)$, both net of depreciation, and net capital inflows $(I-S)$

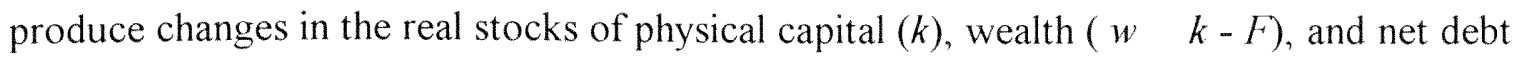


to foreigners $(F)$, respectively. These changes in stocks in turn alter desired $I, S$, and $C A$, calling for new equilibrium real exchange rates. The NATREX reaches a constant level only when and if the economy reaches its long run equilibrium, where both the fundamentals, $Z$, and the stocks of real assets (per unit of effective labor) remain constant. In an economy with no growth of labor, $I, S$, and $C A$ would all be zero in this long-run steady state.

Exogenous fundamental disturbances $(Z)$ - such as changes in thrift and productivity, at home and abroad, and for small countries changes in the terms of trade and world real interest rate- influence the NATREX in two ways:

- they first affect desired investment, saving, or the current account, inducing a change in the NATREX in the medium run

- second, by changing the rates of accumulation of $\mathrm{k}, \mathrm{W}$, and $\mathrm{F}$, the exogenous fundamentals alter the trajectory of the NATREX as it moves towards its new longrun equilibrium. At any point other than long-run equilibrium, the NATREX is a function of both exogenous $(Z)$ and endogenous $(A=k, F)$ fundamentals $(w=k-F)$.

A full NATREX model determines the medium-run equilibrium real exchange rate, $R$ (the NATREX); its trajectory and its eventual long-run equilibrium value, $R^{*}$. Frequent real fundamental disturbances, such as occur in the world, are continually moving the NATREX towards a new long-run equilibrium, so it never actually reaches a steady-state level. The real exchange rate can be depicted at different stages of adjustment:

$R_{t}=R_{t}(Z, A, O)$ actual (disequilibrium) rate

$R=R(Z, A) \quad$ equilibrium rate (NATREX)

$R^{*}=R^{*}(Z) \quad$ steady-state rate.

where $Z$ represents real exogenous fundamental factors, $A$ represents stocks of net real assets, and (? represents short-run cyclical and speculative factors. On empirical work, 
NATREX defenders, estimate the equilibrium exchange rate on the trajectory between $R$ and $R^{*}$, as a function of the exogenous fundamental factors, $Z$, but only the actual rate, $R_{t}$, is observed.

The NATREX is a positive, not a normative, concept of the equilibrium real exchange rate. It is the rate implied by the real fundamentals and by existing economic policies. This approach does not consider whether this policies are socially optimal (and welfare maximizing) or not. It does not tell, either, that this is the optimal exchange rate, only that it is the equilibrium rate implied by the prevailing fundamentals. Like Nurkse (1945), the NATREX approach takes existing trade policy as given, but does not allow for adjustments in the degree of protectionism as a means of achieving an equilibrium real exchange rate. Similarly, it takes the ongoing fiscal policies as given. For example, an exogenous fall in public or private saving in the United States, considered undesirable and inconsistent with long-run social goals of growth and productivity, will affect the NATREX. A NATREX model predicts how such a change will affect the equilibrium real exchange rate, without considering the desirability of the disturbance or the outcome. NATREX models imply no judgment as to whether the real fundamentals themselves are consistent with welfare.

In this respect, the NATREX differs from Williamson (1983) concept of fundamental equilibrium exchange rate (FEER) or his (Williamson 1985) "desired equilibrium exchange rate" (DEER). Williamson's desirable capital flows equal the difference between levels of investment and saving that are not distorted by public policy. This normative element is the major difference between the definitions of the NATREX and Williamson's DEER. 


\subsection{ASSET MARKET DETERMINATION

Two models are discussed here, the monetary approach and the portfolio balance approach. The monetary approach differs from the portfolio balance approach in that domestic and foreign bonds are assumed to be perfect substitutes and thus can be aggregated in one asset. Another consequence of the perfect substitutability of domestic and foreign bonds is that the expected yield in both types of assets is the same so that investors are risk neutral with regard to exchange risks, and the uncovered interest parity holds.

\subsubsection{The Monetary Approach to Exchange Rate Determination (MAER)}

\subsubsection{Flexible Prices.}

The basics of the monetary approach to the exchange rate are found in the Purchasing Power Parity theory, in this model relative long run PPP is assumed. It is stated in equation 1:

$$
e_{t}=a+p_{t}-p_{t}^{*}
$$

where $e_{t}$ is the logarithm of the nominal exchange rate expressed in units of home currency per dollar, $\mathrm{p}_{\mathrm{t}}$ is the domestic price level and $\mathrm{p}_{\mathrm{t}}{ }^{*}$ is the foreign (US.) price level. The second component of the model assumes a stable demand for money function in both countries:

$$
\begin{aligned}
& m_{t}-p_{t}=b_{1} y_{t}-b_{2} i_{t} \\
& m_{t}^{*}-p_{t}^{*}=b_{1} y_{t}{ }^{*}-b_{2} i_{t} *
\end{aligned}
$$


where $m_{t}$ is the logarithm of money supply, $y_{t}$ is the logarithm of real income and $i_{t}$ is the short term interest rate. Asterisks indicate a foreign country variable.

Equations (2.8) and (2.9) can be re-arranged, solving for prices

$$
\begin{aligned}
& p_{t}=b_{1} y_{t}-b_{2} i_{t}+m_{t} \\
& p_{t}^{*}=b_{3} y_{t}{ }^{*}-b_{4} i_{t}^{*}+m_{t} *
\end{aligned}
$$

substituting $\left(2.8^{\prime}\right)$ and $\left(2.9^{\prime}\right)$ into $(2.7)$ we obtain a reduced form equation of the monetary approach to exchange rate determination.

$$
e_{t}=a-b_{1} y_{t}+b_{2} i_{t}+m_{t}+b_{3} y_{t} *-b_{4} i_{t}^{*}-m_{t}^{*}
$$

In this simple equation domestic and foreign assets (the ones that yield $\mathrm{i}$ and $\mathrm{i}^{*}$ respectively) are assumed to be perfect substitutes.(see DeJong 1991) Also the money demand function relates to income and not to wealth, a justification for excluding wealth is that in many cases its time series is highly correlated with that of income.

According to the monetary approach, increases in home money supply cause a depreciation of the domestic currency, an increase in the home interest rate will have the same effect, in this case through the reduction of the demand for domestic currency and thus a rise in the domestic price level. Conversely an increase in foreign money supply and interest rates cause an appreciation of domestic currency. 
In the monetary approach an increase in national income gives rise to an appreciating exchange rate, because the real demand for money increases, given a constant money supply, the price level falls and as a consequence of PPP the exchange rate falls too. This result contrasts with that of the traditional view according to which an increase in income will lead to an extra demand for imports and thus to a depreciating exchange rate.

Equation (2.10) captures all the essence of the monetary approach, however causality is not well defined in the sense that most or maybe all that variables could be endogenous.

\subsubsection{Sticky-Price and Real Interest Differential Monetary Models}

The above model, is also called the flexible-price variant of the monetary approach. The assumption of continuous PPP (i.e. the real exchange rate cannot vary) is very restrictive The supposition that the nominal exchange rate adjusts instantaneously for differences in national price levels, does not always hold. An attempt to restore the monetary model led to the development of a second generation of monetary models, beginning with Dornbusch (1976). The sticky- price monetary model allows for substantial overshooting of both the nominal and the real price-adjusted exchange rates beyond their long-run equilibrium (PPP) levels, because the jump variables in the system-exchange rates and interest rates-

compensate for sluggishness in other variables- notably goods prices. In fact, the main feature of the sticky-price model would be captured in a framework in which the domestic currency prices of domestic goods are sticky but domestic currency prices of foreign goods can move with the exchange rate. This model will be discussed in more detail in the following chapter, given that is one of the theoretical mainstreams that deal with differences between inflation and depreciation rates. 


\subsubsection{THE PORTFOLIO BALANCE MODEL OF EXCHANGE RATE DETERMINATION}

In common with the flexible-price and sticky-price monetary models, the level of the exchange rate in the portfolio balance is determined, at least in the short-run, by supply and demand in the market for financial assets. The exchange rate, however, is a principal determinant of the current account of the balance of payments. Now, a surplus (deficit) on the current account represents a rise (fall) in net domestic holdings of foreign assets, which in turn affects the level of wealth, which in turn affects the level of asset demand, which again affects the exchange rate. Thus, the portfolio balance approach is on itself a dynamic model of exchange rate adjustment, which includes in its terms of reference assets market, the current account, the price level, and the rate of asset accumulation. The seminal contributions to the literature on the portfolio balance approach to exchange rate determination were Kouri (1976), Branson (1977, 1983, 1984), Dornbusch and Fischer (1980), and Isard (1983).

The portfolio balance model, like the sticky-price model, allows one to distinguish between short-run equilibrium (supply and demand equated in asset markets)and the dynamic adjustment the long-run equilibrium ( a static level of wealth and no tendency of the system to move over time). Unlike the sticky-price model, it also allows for the full interaction between the exchange rate, the balance of payments, the level of wealth, and stock equilibrium.

In the short-run (on a day-to-day basis), with the portfolio balance model the exchange rate is determined solely by the interaction of supply and demand in the assets markets. During this period, the level of financial wealth (and the individual components of that 
level) can be treated as fixed. In its simplest form, the portfolio balance model divides net financial wealth of the private sector $(W)$ into three components: money $(M)$, domestically issued bonds $(B)$, and foreign bonds denominated in foreign currency $(F)$; B can be thought as government debt held by the domestic private sector, and $F$ is the level of net claims on foreigners held by the private sector. Since, under a free float, a current account surplus on the balance of payments must be exactly matched by a capital account deficit (that is, capital outflow and, hence, an increase in net foreign indebtedness to the domestic economy), the current account must give the rate of accumulation of $F$ over time.

With domestic and foreign interest rates given by $r$ and $r^{*}$ as before, we write down our definition of wealth and the simple domestic demand functions for its components as follows:

$$
\begin{array}{lllll}
W=M+B+S F & & & \\
M=M\left(r, r^{*}\right) W & M r & 0, & M r^{*} & 0 \\
B=B\left(r, r^{*}\right) W & B r & 0, & B r^{*} \cdot & 0 \\
S F=F\left(r, r^{*}\right) W & F r & 0, & F r^{*} & 0
\end{array}
$$

Relation (2.11) is an identity defining wealth. It is important to note that, in equations 2.12-2.14, the level of wealth is the scale variable, $\mathrm{W}$, and the demand functions are homogeneous in wealth: therefore, they can be written in nominal terms (assuming homogeneity in prices and real wealth, prices cancel out).

This model provides a simple framework for analyzing the effect of, for example, monetary and fiscal policy on the exchange rate. Thus, a contractionary monetary policy (a fall in $\mathrm{M}$ ) reduces nominal financial wealth (through equation (2.11)), and so reduces the demand for both domestic and foreign bonds (through equations (2.13) and (2.14)). As 
foreign bonds are sold, the exchange rates appreciates (the foreign price of domestic currency rises). The effects of fiscal policy (operating through changes in B) on the exchange rate are more ambiguous, depending on the degree of substitution between domestic and foreign bonds. Branson (1984), demonstrates that under rational expectations, real disturbances will generate monotonic adjustment of the exchange rate in the portfolio balance model, while monetary disturbances will generate exchange rate overshooting.

\subsection{CURRENCY SUBSTITUTION AND EXCHANGE RATES}

Research on currency substitution has been motivated by the creation or the development of the European Monetary System on one side and by the occurrence of high inflation processes in several countries. One of the responses to high inflation, by economic agents, is to protect the value of their wealth. Changing theirs (domestic) monetary holdings for foreign exchange is one way to do so. Currency substitution is defined as the use in a given country of multiple currencies as media of exchange.

Few national currencies survive the destructive power of high inflation. A currency whose value declines over time, often in an unpredicted manner, can not serve as a store of value. Nominal prices with an ever-increasing number of digits make the use of a currency as a unit of account inconvenient and empty of much meaning. Sellers become reluctant to accept as a medium of exchange a currency with uncertain value. The phenomenon of currency substitution is nothing new: large quantities of foreign currencies circulated $n$ most of the economies that suffered hyper inflation after the two world wars. In Germany, for instance, it has been estimated that by October 1923, the real value of foreign 
currencies circulating was at least equal to and perhaps several times the real value of the domestic currency.

There is a vast literature on currency substitution, inflation and exchange rate variability. It began with Calvo and Rodriguez (1977) and continued with Liviatan (1981), Calvo (1985), Engel (1989), Lee (1992), Calvo and Vegh (1993) and Heng-Fu Zou (1993) just to mention some of them.

Calvo and Rodriguez (1977) show in a model of a small economy in which residents are allowed to hold foreign currency, that an increase in domestic money growth will bring about an immediate real depreciation of the currency. Increases in the rate of growth of money are associated with higher inflation. Here inflation adduces changes in domestic currency prices. Higher inflation increases the real demand for foreign money as people switches from domestic to foreign currency in their portfolios. The country can acquire this money only through a trade surplus, which requires the real depreciation. Liviatan (1981) provides a parallel model to Calvo and Rodriguez in which agents maximize a utility function. Both, domestic and foreign, moneys are included as arguments of that function and also consumption goods. Liviatan concludes that an increase in domestic money growth leads to a real appreciation domestically, and thus the Calvo-Rodriguez model is not correct in a model in which agents optimize. Engel (1989), demonstrates that the Calvo and Rodriguez results hold up in a utility maximizing model, if the assumption that the two monetary balances -domestic and foreign- are non-cooperant in utility is made. If the two moneys were non-cooperant, a smaller amount of domestic currency holdings leads to a large marginal utility of liquidity services from the foreign currency. Zou (1993) addresses the problem of currency substitution in the same optimization model but adds the government financing its deficits through money creation, he arrives to 
the same conclusion as Engel (1989), "if the government transfer its inflation tax to the public, dollarization will only happen when two currencies are non-cooperant in generating liquidity service".

\subsection{EMPIRICAL WORK}

Most of the empirical work related to exchange rate determination has focused on the Purchasing Power Parity theory and in the Monetary Approach to the Exchange Rate (MAER) determination. Recently, a large number of studies on PPP and the MAER has been performed using contemporary tests of cointegration. The applicability of the MAER has been challenged due to poor empirical results found for the case of industrial countries -see Baillie and Selover (1987) and also McNown and Wallace (1989). Baillie and Pecchenino (1991) have added uncovered interest rate parity to the traditional monetary model for exchange rates, and have used this method to test for an equilibrium relationship between the United States and the United Kingdom. Using cointegration techniques they have found strong evidence for such a relationship in the money demand equations, but have found no convincing evidence in the consolidated MAER equation. They hypothesize that the weakness in the overall MAER tests results is non-stationarity in the Purchasing Power Parity (PPP) condition.

PPP, which forms the basis of the long-run equilibrium in the monetary approach, has performed poorly. Many empirical studies exist which report substantial deviations from purchasing power parity (Dornbusch, 1976; Frenkel, 1981; Kravis at al., 1975; Genberg, 1978; Stockman, 1978 among others). Evidence favorable to PPP has generally required tests over extensive time periods. Recent articles, using cointegration tests, exhibit contradicting results about the long run behavior of the real exchange rate, for instance, 
Whitt (1992) and Glen(1992) reject the random walk hypothesis in favor of the PPP approach. On the other hand Taylor (1988) and Mark (1990) find evidence unfavorable to the PPP hypothesis. All this studies have been done for industrialized countries.

The tests have been also applied to high inflation economies such as Argentina, Chile and Israel by McNown and Wallace (1994) with ambiguous or not very strong results for the MAER model. In this study, tests are going to be conducted in the McNown and Wallace fashion, however, an important change is to be made: instead of using the domestic interest rate (or expected inflation) as the opportunity cost of holding money, I will use the expected rate of devaluation plus the interest rate for deposits denominated in US dollars. The main justification for this is the dollarization process that accompanies most inflationary economies (this is based on the recent experience of Latin American countries).

In the presence of high-inflation, high rates of money growth and large changes in nominal exchange rates (relative to the United States) may make any tendency to equilibrium more explicit than those among the industrial countries that have experienced relatively similar monetary events. In addition, for high-inflation countries, monetary factors, rather than non-transitory real factors, would be expected to dominate exchange rate changes.

\subsection{HYPER INFLATION}

Most of the recent literature on hyperinflation concentrates on the stabilization component of the process (Bruno, Di Tella, Dornbusch, Fisher 1988, among others). The purpose of this section is to highlight the main features of hyperinflation before the stabilization and to show under what circumstances the process originates. 
Philip Cagan (1956) derived a model composed of two equations, an equation giving the demand for money and an equation describing the formation of expectations. The money demand function is giving by:

$$
m \equiv \frac{M}{P}=c \exp \left(-a \pi^{*}\right)
$$

where $c$ is a constant term and $\pi^{*}$ is the expected rate of inflation. The higher the expected inflation, the lower will be the demand for real money balances. Two important implicit assumptions are implicit in this formulation. The first is that output is given and thus part of the constant term c. The second is that the real interest rate is constant and thus also included in the constant term-- this is why the expected inflation rate, and not the nominal interest rate, appears in (2.15). The main rationale for this functional form is convenience (Blanchard and Fisher 1989), though it appears consistent with the data from hyperinflations. In an equilibrium the real money stock must be equal to the money demand, and (2.15) can be interpreted as an equilibrium equation.

For the expectations equation, Cagan assumed adaptive expectations

$$
\begin{aligned}
& \frac{d \pi^{*}}{d t}=b\left(\pi-\pi^{*}\right) \\
& \mathrm{b}>0
\end{aligned}
$$

If current inflation exceeds expected inflation, expected inflation increases. The coefficient $\mathrm{b}$ reflects the speed at which individuals revise their expectations. Note that the expected inflation depends only on past inflation. Given the dynamics of money growth, equations (2.15) and (2.16) determine the dynamics of inflation. 
The first question asked by Cagan is the following: When the money growth is constant at a rate $\sigma$, will inflation converge to $\sigma$, or will it take off on its own toward hyperinflation? To answer that question, he differentiated (2.15) after taking logs. This gives

$$
\sigma-\pi=-a\left(\frac{d \pi^{*}}{d t}\right)
$$

eliminating $\left(\frac{d \pi^{*}}{d t}\right)$ between $(2.16)$ and (2.17) gives a relation between $\pi, \pi^{*}$, and $\sigma$ :

$$
\sigma-\pi=a b\left(\pi-\pi^{*}\right)
$$

if $a b<1$, the equilibrium is stable, but if $a b>1$ the equilibrium is unstable. If $b$ is large higher inflation leads money holders to quickly revise upward their expectations of inflation and thus to attempt to reduce their money holdings; given money growth, this leads to further inflation, further revisions and accelerating inflation. If $a$ is large, an increase in inflation that leads to an upward revision of expected has a strong negative effect on money demand, leading again to accelerating inflation. Accordingly, if individuals have adaptive expectations, it is possible for hyperinflation to result not from accelerating money growth but rather from a self-generating unstable process. Cagan calculated a and $\mathrm{b}$ and concluded that the stability condition was satisfied for most hyperinflations, implying that hyperinflation was due to unstable money growth rather than an inherent instability of the private economy.

The second question raised by Cagan was: If the equilibrium is stable what is the maximum amount of seigniorage that the government can collect? Steady state seigniorage is maximized when $\sigma=1 / \mathrm{a}$. The analysis of seigniorage is also called inflation tax analysis. The inflation tax is the tax imposed on money holders as a result of inflation. It is related 
but not necessarily identical to seigniorage. The actual tax that inflation imposes on money holders is the loss in the value of their real balances, $\pi \mathrm{M} / \mathrm{P}$; seigniorage is $\sigma \mathrm{M} / \mathrm{P}$. Only when $\pi=\sigma$ the two are equal. That holds in a steady state when there is no output growth, but not generally.

Patinkin (1993), analyzing Israel's stabilization program points out the problems that high inflation causes to the economies. During the period of high inflation in Israel, no nominal value was fixed, all variables were indexed. Patinkin asked himself: if everything was indexed so that the inflationary process continued smoothly without adverse effects either on the real variables of the economy or on the distribution of income, then why be concerned with it? Why not just let it go on? Part of the answer to this question begins with the simple fact that the inflationary process in Israel (as well as those of Peru, Argentina, etc.) was not smooth. It generated some changes in real variables and hence some social and economic costs. The most intangible cost: the feeling of discomfort that invade people from the constant changes in prices and exchange rate. A discomfort that is in part generated by fears that the increase in their nominal income might lag behind the rate of inflation. In addition, rapid inflation also impairs the efficiency with which the price system conveys information about the relative prices of commodities. Since all prices are in a state of flux, it is difficult to know what is relatively expensive and what is relatively cheap. People realize that the CPI does not represent their consumption patterns, then indexation is not perfect.

In addition, there is the familiar and most concrete "shoe-leather" cost of inflation, when inflation proceeds at a rate, say, over 10 percent per month then the average earners find it necessary to take steps at the beginning of the month to preserve the real value of their salaries for the purchases they plan to make during the ensuing month. So they must spend 
much time and energy standing in lines at the bank to make the short-term financial transactions that will serve this purpose. When people try to avoid this cost by switching their portfolios and purchase in advance -say, at the beginning of the month- all their consumption goods and also invest in consumption goods, then, money demand for transaction purposes goes down. Increasing nominal money supply is more than offset by rising prices such that real money supply decreases. This is a characteristic of hyper inflation and this mechanism is crucial to explain the main hypothesis of this dissertation.

What is true for the individual household is even more true of business enterprises. One of the scarce resources in any economy is the time and thought that executive business devote to the efficient management of their respective firms. So there is indeed a cost to the economy when in a period of rapid inflation these scarce resources are primarily devoted not to increasing the efficiency of production, and not to increasing that of marketing, but to increasing the efficiency of managing the cash flow. For with inflation proceeding at 10-20 percent or more per month, the most productively-efficient firm will go bankrupt if it does not manage its cash flow properly. So the most important executive in a firm is then not the vice-president in charge of production, and not the vice-president in charge of marketing, but the vice-president in charge of finance and accordingly of this flow. 


\section{CHAPTER 3}

\section{THE MODEL}

\subsection{Hypothesis}

As it has been stated in Chapter II, Purchasing Power Parity theory of exchange rate determination stays as a bench-mark to judge the level of the exchange rate. I will use the definition of real exchange rate based on the PPP approach, in order to delimit whether a currency is overvalued or undervalued.

The definition of real exchange rate that follows from PPP theory is:

$$
\varepsilon_{t}=\frac{E_{t} P_{t}^{*}}{P_{t}}
$$

$\varepsilon_{f}=$ Real exchange rate at time $\mathrm{t}$

$E_{t}=$ Nominal exchange rate at time $\mathrm{t}$. The nominal exchange rate is defined as the number of units of domestic currency paid for one unit of foreign currency.

$P_{t}^{*}=$ world price index

$P_{t}=$ domestic price index

Differentiating equation (3.1) with respect to time:

$\frac{\partial \varepsilon}{\partial t} \equiv \dot{\varepsilon} ;$ the same notation is used for the other variables.

$$
\dot{\varepsilon}=\frac{\left(\dot{E} P^{*}+\dot{P}^{*} E\right) P-\dot{P} E P^{*}}{P^{2}}
$$




$$
\dot{\varepsilon}=\frac{\dot{E} P^{*}}{P}+\frac{\dot{P}^{*} E}{P}-\frac{\dot{P}}{P} \frac{E P^{*}}{P}
$$

from (3.1)

$$
\frac{P^{*}}{P}=\frac{\varepsilon}{E} ; \frac{E}{P}=\frac{\varepsilon}{P^{*}}
$$

plugging (3.1') into (3.3)

$$
\dot{\varepsilon}=\frac{\dot{E} \varepsilon}{E}+\frac{\dot{P}^{*} \varepsilon}{P^{*}}-\frac{\dot{P} \varepsilon}{P}
$$

by definition:

$$
\begin{aligned}
& \frac{\dot{\mathrm{E}}}{\mathrm{E}} \equiv \delta, \frac{\dot{\mathrm{P}}^{*}}{\mathrm{P}^{*}} \equiv \pi^{*}, \frac{\dot{\mathrm{P}}}{\mathrm{P}} \equiv \pi \\
& \dot{\varepsilon}=\varepsilon\left(\delta+\pi^{*}-\pi\right)
\end{aligned}
$$

At the steady state: $\dot{\varepsilon}=0$

$$
\begin{aligned}
& \dot{\varepsilon}=\varepsilon\left(\delta+\pi^{*}-\pi\right)=0 \\
& \left(\delta+\pi^{*}-\pi\right)=0 \\
& \delta+\pi^{*}=\pi
\end{aligned}
$$

The hypothesis that, as a response to a monetary shock, the real exchange rate depreciates under low inflation rates but appreciates under high levels of inflation can be expressed graphically as it is shown in Figure 3.1. On the vertical axes we measure the rate of devaluation (foreign inflation is assumed to be zero). On the horizontal axes, we measure 
the rate of domestic inflation. The straight line is a 45 degree line, the one that equalizes the rate of change of the nominal exchange rate and rate of inflation. The curve, depicts the relationship between the two variables; for low levels of inflation the rate of depreciation is higher and for high levels of inflation, the curve is below the 45 degree line, which means that inflation is greater than the nominal depreciation of the exchange rate.

Figure 3.1 .

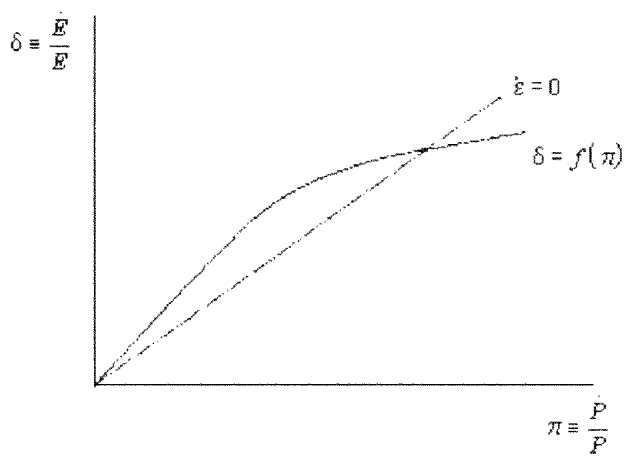

It is not the purpose of this dissertation to find an explicit function $f$ for the relationship $\delta=f(\pi)$ but to prove that the way it has been drawn (above the 45 degree line for low inflation and below it for high inflation) is correct. 


\subsection{A Model of Exchange Rate Determination}

\subsubsection{Sticky Prices}

I build up Dornbusch's (1976) model, in this section I will describe the main features of his model and in section 3.2.2 I will relax the assumptions of fixed output and sticky prices in order to determine the behavior of the exchange rate once output and prices are free to vary. Section 3.2.1 shows how, in the short run, the exchange rate overshoots. This explains the segment of the function $\delta=f(\pi)$, that lies above the 45 degree line in Figure 2 .

\section{The model.}

The model considers a small open economy in the world capital market, thus, it faces a given interest rate. Capital mobility will ensure equalization of expected net yields. The difference between the domestic interest rate and the world interest rate is the expected rate of depreciation of domestic currency. The world price of imports is given. It is also assumed that domestic output is an imperfect substitute for imports and that aggregate demand for domestic goods will determine their absolute and relative price. Assets determined in terms of domestic and foreign currency are assumed to be perfect substitutes given a proper premium to offset anticipated exchange rate changes.

$$
r=r^{*}+x
$$

where $r$ is the domestic interest rate

$r^{*}$ is the foreign interest rate

$x$ is the expected rate of depreciation. 
Equation (3.7) represents perfect capital mobility and it is assumed that incipient capital flows will make (3.7) hold at every point in time. This is the so called uncovered interest parity condition. Risk is assumed away.

\section{Expectations}

$$
x=\theta(\bar{e}-e)
$$

where $e$ is the logarithm of the current exchange rate

$\bar{e}$ is the logarithm of the long-run exchange rate

$\theta$ is the speed of adjustment

Equation (3.8) depicts the way expectations are formed, the expected depreciation is proportional to the difference between the current exchange rate and its long-run equilibrium value.

\section{Money Market Equilibrium}

$$
-\lambda r+\phi y=m-p
$$

where $m$ is the logarithm of the nominal quantity of money

$p$ is the logarithm of the price level

$y$ is the logarithm of real income

$\lambda$ is the sensitivity of money demand with respect to interest rate

$\phi$ is the sensitivity of money demand with respect to income

this is a well known money market equilibrium condition where demand for money depends on the domestic interest rate and real income and is equal to real money supply. In this section $m$ and $y$ will be taken as given.

Equations (3.8) and (3.9) together yield 


$$
r=r^{*}+\theta(\bar{e}-e)
$$

now let us combine (3.7a) and (3.9) to get

$$
p-m=-\phi y+\lambda r^{*}+\lambda \theta(\bar{e}-e)
$$

equation (3.10) establishes the relationship between the spot exchange rate, the long-run exchange rate and the price level, at equilibrium in the money market. In the long run, with a stationary money supply, $\bar{e}=e$ and $r^{*}=r$. The long-run equilibrium price level is given by

$$
\bar{p}=m+\left(\lambda r^{*}-\phi y\right)
$$

The long run equilibrium price level depends only on money supply, output and the foreign interest rate. This is because in the long run, we assume, there is no difference between the domestic and the foreign exchange rate. Substituting (3.11) into (3.10)

$$
e=\bar{e}-\frac{1}{\lambda \theta}(p-\bar{p})
$$

this last equation tell us that, for given long run values of exchange rates and prices, there is an inverse relationship between the price level and the exchange rate, this equation is drawn as the locus equilibrium QQ in Figure 3.2. An increase in prices raise the interest rate. The exchange rate will appreciate exactly to the point where expected depreciation exactly offsets the increase in interest rates. 


\section{Goods Market}

In the goods market, demand for domestic output is defined as a function of the relative price of domestic goods and imports, real income and the domestic interest rate. It takes the structure

$$
\ln D=u+\kappa(e-p)+\gamma y-\sigma r
$$

where $D=$ demand for domestic output, $u$ is a shift parameter; the complete relative price adjustment in (3.13) is $e+p^{*}-p$ where $p^{*}$ is the logarithm of the foreign price level, $\mathrm{P}^{*}$, which is assumed to be 1 , therefore $p^{*}=0$. A decrease in the relative price for domestic goods increases demand, the same effect will take place when real income increases or the domestic interest rate decreases. The rate of increase in the price level of domestic goods is defined in equation (3.14) as proportional to an excess demand measure

$$
\dot{p}=\omega \ln \frac{D}{Y}=\ln D-\ln Y
$$

note that $\ln Y=y$, we can rewrite equation (3.14) as

$$
\dot{p}=\omega[u+\kappa(e-p)+(\gamma-1) y-\sigma r]
$$

In the long run, markets clear and exchange rates are constant, $\dot{p}=0$ and $r^{*}=r$. Equation (3.14a) becomes:

$$
\bar{e}=\bar{p}+\frac{1}{\kappa}\left[\sigma r^{*}+(1-\gamma) y-u\right]
$$

note that in the long-run $\bar{e}=e$, and $\bar{p}=p$. 
Let us substitute the definition of the spot exchange rate in (3.12) into (3.14a) to obtain the dynamics of inflation.

$$
\dot{p}=\omega\left\{u+\kappa\left[\bar{e}-\frac{1}{\lambda \theta}(p-\bar{p})-p\right]+(\gamma-1) y-\sigma r\right\}
$$

this equation may be reduced by using the definition of the long-run rate in (3.15) and also equation (3.7a)

$$
\dot{p}=-\omega(p-\bar{p})\left(\kappa+\frac{\kappa+\sigma \theta}{\lambda \theta}\right)=-v(p-\bar{p})
$$

where

$$
v=\omega\left(\kappa+\frac{\kappa+\sigma \theta}{\lambda \theta}\right)
$$

Equation (3.17) is a first order differential equation, which can be solved to yield

$$
p(t)=\bar{p}+\left(p_{0}-\bar{p}\right) \exp (-v t)
$$

(3.18) states that the price of domestically produced goods will converge to its long-run equilibrium. As time goes by an $t$ increases the second term on the right hand side of equation (3.18) goes to zero.

(3.18) can be rewritten as

$$
p(t)-\bar{p}=\left(p_{0}-\bar{p}\right) \exp (-v t)
$$

replace (3.18a) into (3.12) to get 


$$
e=\bar{e}-\frac{1}{\lambda \theta}\left(p_{0}-\bar{p}\right) \exp (-v t)
$$

using again (3.12) we get

$$
e(t)=\bar{e}+\left(e_{0}-\bar{e}\right) \exp (-v t)
$$

The exchange rate will, also, converge to its long-run level. If prices are initially below their long-run level the exchange rate will appreciate, and if prices are initially above the long-run level the exchange rate will depreciate.

\section{The adjustment process}

The adjustment process of the economy may be described with the aid of Figure 3.2

Figure 3.2

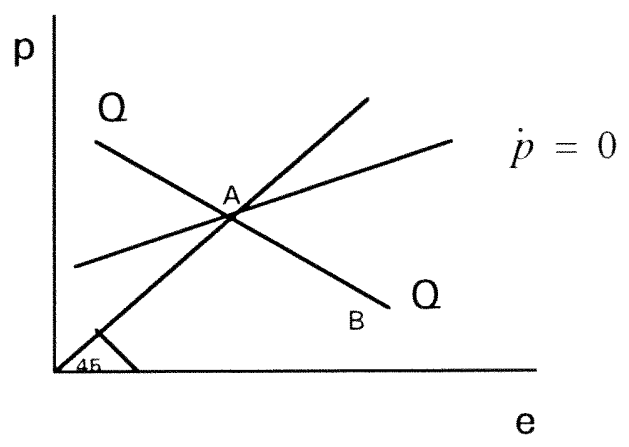

In Figure 3.2 the negatively sloped QQ schedule is the representation of equation (3.12), it characterizes money market equilibrium and also the equalization of net asset yields. The $\dot{p}=0$ line, show combinations of price levels and spot exchange rates for which the 
goods market is in equilibrium. This line may be derived from equation (3.14a), setting $\dot{p}=0$ and substituting for the domestic interest rate from (3.9)

$$
p=\left(\frac{\kappa \lambda}{\kappa \lambda+\sigma}\right) e+\left(\frac{\sigma}{\kappa \lambda+\sigma}\right) m+\left(\frac{\lambda}{\kappa \lambda+\sigma}\right)\left(u+(\gamma-1) y-\frac{\phi \sigma y}{\lambda}\right)
$$

Points above the $\dot{p}=0$ schedule, represent excess supply of domestic goods, in other words, demand is too low for the given output level and/or the exchange rate is too low that demand is shifted from domestic goods to foreign goods (recall that the nominal exchange rate is defined as the number of units of domestic currency paid for one unit of foreign currency). Under this condition the economy experiences falling (domestic) prices. Conversely, points below and to the right the schedule represent an excess demand and rising prices. An increase in the exchange rate creates an excess demand for domestic goods by lowering their relative price. To restore equilibrium, domestic prices will have to increase. The $\dot{p}=0$ schedule slopes upward and is flatter than the 45 degree line for the following reason: an increase in the exchange rate creates an excess demand for domestic goods by lowering their relative price. To restore equilibrium, domestic prices will have to increase, though proportionately less since an increase in domestic prices affects aggregate demand, both via the relative price effect and via higher interest rates.

For any given price level, the exchange rate adjusts instantaneously to clear the asset market, which means that at every point in time we are at the QQ schedule with money market equilibrium and net asset yield equalized. In contrast, goods market equilibrium is only achieved in the long-run. It is the goods market that takes the whole economy to long-run equilibrium by inducing rising or falling prices. Specifically, an initial position such as point $\mathrm{B}$, with a price level below the long run level and, correspondingly, an 
exchange rate higher than the long run equilibrium value, implies an excess demand for goods because domestic output commands a low relative price and because the interest rate is low. Consequently, prices will be rising and the excess demand will be reduced over time. In the process the exchange rate appreciates. As interest rates rise, as a consequence of declining balances, the spot rate will approach the long run rate. Once the long run equilibrium is reached (at point $\mathrm{A}$ ), domestic interest rates is equal to the world interest rate, the goods market clear, prices are constant and expected depreciation is zero.

\subsubsection{The Overshooting Process}

Dornbusch analyzes the effects of a monetary expansion and the corresponding adjustment process which are portrayed in Figure 3.3. The initial equilibrium takes place at point A, where $\bar{p}$ and $\bar{e}$ are the long-run equilibrium values for the price level and the exchange rate respectively. The price level is determined according to equation (3.11), which states that it depends on money supply, the world interest rate and domestic output. The long run equilibrium value for the exchange rate is a function of the long run equilibrium price, the world interest rate, and domestic output. This is given by equation (3.15). As in Figure 3.2, the QQ schedule that combines monetary equilibrium and arbitrage of net expected yields is drawn for the initial quantity of money. An increase in the nominal quantity of money that is expected to persist will give rise to a disequilibrium in both the goods market and the asset market, at the initial exchange rate and price. The QQ schedule shifts out, the new asset market equilibrium will present itself at the $Q^{\prime} Q^{\prime}$ schedule, the shift is proportionately equal to the increase in the nominal quantity of money, higher prices and a devaluation are expected. 
Figure 3.3

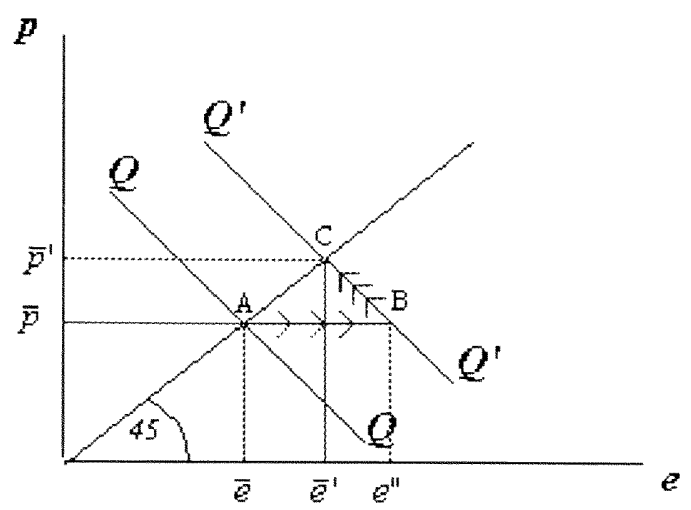

The new long-run equilibrium is at point $\mathrm{C}$, where both goods and asset markets clear and the variation in the price level and the exchange rate exactly reflects the changes in the quantity of money. It follows from the homogeneity properties of the model that the line $\dot{p}=0$ (not drawn in Figure 3.3) passes through point $\mathrm{C}$. The outcome that in the long-run all changes are proportional (homogeneity result) is associated with the fact that there is no source of money illusion or long-run price rigidity in the system.

The path of adjustment is described in Figure 3.3. At the initial price level, a higher money stock reduces domestic interest rates, economic agents with rational expectations await a depreciation in the long-run and, therefore at the current exchange rate they expect a depreciation. Both factors reduce the attractiveness of domestic assets and induce capital outflows, thus the spot rate depreciates. The extent of that depreciation must be large enough to exceed the new long-run equilibrium value of the exchange rate, only in that way the economic agents will expect an appreciation that compensates the reduced domestic interest rate. This is shown in Figure 3.3 by the move in from point $\mathrm{A}$ to point B. In this framework, overshooting of the exchange rate is closely related to the 
assumption that asset markets clear quickly relative to goods markets. With output fixed, the unanticipated money supply increase requires a reduction in the domestic interest rate to maintain money market equilibrium. Given world interest rates, domestic interest rates can decline only if agents expect that the domestic currency will appreciate. From the uncovered interest parity condition -equation (3.7): $r=r^{*}+x$ - domestic interest rates decline if $x$ becomes negative. This implies that, to maintain money market equilibrium over the short run, the exchange rate will have to move above its full equilibrium level, giving rise to an expected domestic currency appreciation, allowing a reduction in domestic interest rates and an increase in money demand that matches the money supply expansion.

The algebraic expression for the overshooting is obtained from equation (3.12), noting that $d \bar{e}=d m=d \bar{p}$ and also considering the sticky prices assumption for the short run: $\frac{d p}{d m}=0$ we get:

$$
\frac{d e}{d m}=1+\frac{1}{\lambda \theta}
$$

the extent of the overshooting depends on the sensitivity of money demand with respect to the interest rate and also on the speed of adjustment of expectations. A high sensitivity of money demand to changes in the interest rate will reduce the overshooting because a small reduction in the interest will be enough to increase money demand to restore equilibrium (after an increase in money supply). In turn this small change in the interest rate requires only a small expectation of appreciation to compensate it. A similar interpretation may be given to the coefficient of expectations. 
So far, only the adjustment path from point $\mathrm{A}$ to point $\mathrm{B}$ has been explained. The process that follows from the short run equilibrium point $\mathrm{B}$ to the long-run equilibrium point $\mathrm{C}$ can be outlined as follows: in Figure 3.3, at point B, there is an excess demand for goods. The excess demand for goods originates from the reduction in the relative price of domestic to foreign goods due to the depreciation and also due to a lower interest rate. Both of these factors determine independent channels through which monetary changes affect demand for domestic output. The exchange rate channel is the one in the Mundell-Fleming model. A lower relative price for domestic output increases aggregate demand and imposes pressure on prices rather than an increase in output. The effect of the exchange rate on demand for domestic output will be larger, the higher the price elasticity of demand relative to the interest response of aggregate spending.

As described, on impact the expansionary monetary policy produces a lower interest rate and lower domestic relative prices. This situation will cause domestic prices to rise and therefore real money balances will decline, interest rates will go up and the exchange rate will appreciate.

\subsubsection{Flexible Output and Prices under Currency Substitution.}

In this section we depart from Dornbusch's model by allowing prices and output to change in the short run, and also by considering currency substitution. These assumptions are more realistic to analyze a hyper inflationary economy and portray precisely the conditions prevailing in Peru between September 1988 and July 1990.

The purpose of this section is to show under what circumstances the exchange rate undershoots, which is equivalent to ask ourselves when does the price level changes faster 
than the nominal exchange rate? Or when does the real exchange rate decline? Here, the assumption of fixed output is relaxed. Equation (3.14a) is replaced by an equilibrium condition for the goods market

$$
y=\alpha[u+\kappa(e-p)-\sigma r]
$$

where

$$
\alpha \equiv \frac{1}{1-\gamma}>0
$$

$r$ is the domestic interest rate

$u$ is a shift parameter

$p$ is the logarithm of the price level

$y$ is the logarithm of real income

$e$ is the logarithm of the current exchange rate

$\gamma$ is the marginal propensity to consume

$\sigma$ is the interest rate sensitivity of investment. (or agg. demand)

$\mathrm{k}$ is the speed of adjustment of aggregate demand with respect to the relative price tradable to non tradable goods.

In addition to (3.21) we need to define a price adjustment equation:

$$
\dot{p}=\omega(y-\bar{y})
$$

where $\bar{y}$ indicates the full-employment level of output. The price equation is the Phillipscurve relation. Excess demand puts upward pressure on the price level. The specification of the money market and exchange rate expectations remains unchanged, and so does equation (3.10) that represent these relations. 
In the long-run, by definition, $y=\bar{y}$ and $r=r^{*}$. Replacing these definitions in (3.21) we get the long-run goods-market equilibrium.

$$
\bar{y}=\alpha\left[u+\kappa(\bar{e}-\bar{p})-\sigma r^{*}\right]
$$

subtracting (3.23) from (3.21), we get the goods-market equilibrium condition in terms of deviations from long-run equilibrium.

$$
y-\bar{y}=\alpha(\kappa+\sigma \theta)(e-\bar{e})+\alpha \kappa(\bar{p}-p)
$$

the interest rate disappeared from the equation because we used the uncovered interest parity condition $r^{*}-r=\theta(e-\bar{e})$.

\section{Currency Substitution}

This variation of the model is based on the fact that perfect capital mobility is not a plausible assumption for a situation where both the rate of inflation and the rate of depreciation are very high, circumstances frequently associated to social and economic instability when we may expect capital outflows but not capital inflows. Calvo and Végh (1993) identify currency substitution as an inherent aspect of highly inflationary economies. Lee (1992) explores the case of currency substitution as opposite to perfect capital mobility.

We disregard, for the short run equilibrium, equations (3.7) and (3.8), consequently we relax the assumption of perfect capital mobility. Under a conditions of high inflation and 
currency substitution the uncovered interest parity condition does not hold in the short run. In what follows, the equations will be numbered according to its correspondingly comparable one from section 3.2.1, I will add at the end the term CS.

Equation (3.9) becomes

$$
-\lambda r+\phi y-\theta(\bar{e}-e)=m-p
$$

we added the term $\theta(\bar{e}-e)$, expected devaluation. Under currency substitution if the public expects a devaluation, they will switch their money holdings from domestic to foreign currency. We associate the process of currency substitution to an unstable economy with high inflation. The equilibrium in $(3.9 \mathrm{cs})$ is not and ad-hoc equation. The money demand function on the left hand side of the equation is derived from agents' optimal behavior. Engel (1989), Lee (1992) and Zou (1993) derive this type of money demand function assuming and infinitely lived household that gets utility from consumption of domestic and tradable goods and from holding domestic and foreign currency.

Let us apply to the equation of money market equilibrium the same procedure that was followed with the goods market from equations 3.21 through 3.24. (i. e. use $y=\bar{y}, p=\bar{p}$, and $r=r^{*}+\theta(\bar{e}-e)$. Under currency substitution we may interpret $r^{*}$ as the interest rate for local deposits denominated in foreign currency.

$$
\bar{p}-m+\phi \bar{y}=\lambda r^{*}+\theta(\bar{e}-\bar{e})
$$

Note that the last term in the right hand side of equation (3.25) equals zero. Subtracting (3.25) from $(3.9 \mathrm{cs})$ we get 


$$
(p-\bar{p})+\phi(y-\bar{y})=(\lambda \theta+\theta)(\bar{e}-e)
$$

Now, let us solve simultaneously equations (3.24) and (3.26). We solve for $(y-\bar{y})$ and $(e-\bar{e})$, such that the output level and the spot exchange rate became a function of the prevailing price level. After some manipulation the following solutions are obtained:

$$
e-\bar{e}=-\frac{1-\phi \alpha \kappa}{\Gamma}(p-\bar{p})
$$

where

$$
\Gamma=(\lambda \theta+\theta)+\phi \alpha(\kappa+\sigma \theta)
$$

and the solution for the output level

$$
y-\bar{y}=-z^{\prime}(p-\bar{p})
$$

The discrepancy between actual and full employment is proportional to the discrepancy between current price level and its long run equilibrium value. If actual output is larger than its full employment level, it means an excess supply, therefore we should expect current prices below their long run value.

where

$$
z^{\prime} \equiv \frac{\alpha \kappa(1+\theta)}{\Gamma}
$$

Substituting (3.28) into (3.22) yields the equilibrium rate of inflation as a function of the price level

$$
\dot{p}=-\omega z^{\prime}(p-\bar{p})
$$


Equation (3.29) states that inflation converges monotonically to the long run level. Thus, if the price level is larger than the long run equilibrium value it will decline monotonically until it reaches the equilibrium level.

Combining equations (3.27) and (3.29) we get:

$$
(\overline{\mathrm{e}}-\mathrm{e})=\frac{1}{w}\left(\frac{\phi \alpha \kappa-1}{\alpha \kappa(1+\theta)}\right) \dot{\mathrm{p}}
$$

If the term

$$
\left(\frac{\phi \alpha \kappa-1}{\alpha \kappa(1+\theta)}\right)
$$

is positive for a given change in the price level the gap between the long run equilibrium value of the exchange rate and the spot exchange rate is positive i.e. domestic currency is overvalued. If that term is below zero, for a given price change, the exchange rate overshoots.

Equation (3.30) must be analyzed as an observation at a given point in time. Where the dependent variable is the gap between the long-run value and the spot exchange rate. What makes the difference between a circumstances of low inflation and periods of high inflation is the stability of the coefficients of the money demand function and also those of the aggregate demand function. In order to determine the sign of the expression (3.31) we compare two different states of the economy: low inflation or high inflation (we evaluate whether $\dot{p}$ is high or low) 
Let us start from a hyper inflation situation. Under this circumstances velocity of money increases very rapidly, economic agents spend all their income almost immediately in order to avoid paying the inflation tax that might deteriorate completely the purchasing power of their wages or salaries. If possible, they will materialize immediately all their programmed purchases of the month the same day they receive their salaries. We may interpret this as the marginal propensity to consume goes to one.

$\alpha \equiv \frac{1}{1-\gamma}>0$

if that is the case $\alpha$ will go to infinity

$$
\lim _{\alpha \rightarrow \infty}\left(\frac{\phi \alpha \kappa-1}{\alpha \kappa(1+\theta)}\right)=\frac{\phi \kappa}{\kappa(1+\theta)}>0
$$

this implies that high inflation is directly related to a situation of undershooting. The spot exchange rate will lie below its long run equilibrium. We can also assert that the higher the inflation rate, the larger is the gap $(\bar{e}-e)$. Note that under complete indexation, there is no reason why we should expect a change in relative prices neither a change in the marginal propensity to consume, in this case undershooting will not occur.

Income elasticity of money demand, $\phi$, is assumed to be a low coefficient. It becomes lower when inflation is high. The importance of real variables reduces under hyper inflation and income is not an exception. If money is still demanded for transaction purposes $\phi$ does not go to zero. That coefficient will go to zero if complete currency substitution takes place or any other medium of exchange replaces domestic money, say barter. 
The coefficient that captures the speed of adjustment of relative price variability " $\kappa$ ", may be interpreted as the degree of awareness of the public with respect to differences in prices. When inflation is very high we expect people to search more for prices given that they know (or they learn almost immediately) that relative price variability increases with hyper inflation, hence if $\kappa$ has to change it will increase as inflation increases.. The behavior of " $\mathrm{K}$ ", reinforces our previous findings.

\subsubsection{A Monetary Expansion}

In order to explore a flavor of the dynamics of inflation we, now, consider the effect of a monetary expansion. Under the homogeneity properties of the model, in the long-run, an increase in money provokes an equiproportionate increase in prices and the exchange rate, i.e. $d m=d \bar{p}=d \bar{e}$. The impact effect of a monetary expansion may be obtained from equation (3.27)

$$
\frac{d e}{d m}-\frac{d \bar{e}}{d m}=-\frac{(1-\phi \alpha \kappa)}{\Gamma}\left(\frac{d p}{d m}-\frac{d \bar{p}}{d m}\right)
$$

If we relax Dornbusch's assumption of fixed prices in the short-run and assume $\frac{d p}{d m} \neq 0$, from the expression (3.32) we get

$$
\begin{aligned}
& \frac{d e}{d m}-1=\frac{(\phi \alpha \kappa-1)}{\Gamma}\left(\frac{d p}{d m}-1\right) \\
& \frac{d e}{d m}-\frac{d p}{d m}=\left[\left(\frac{\phi \alpha \kappa-1}{\Gamma}\right)-1\right]\left(\frac{d p}{d m}-1\right)
\end{aligned}
$$


Let us remember Dornbusch's expression for the monetary expansion

$$
\frac{d e}{d m}=1+\frac{1}{\lambda \theta}
$$

In expression (3.20) overshooting takes place unambiguously. Under (3.33) the exchange rate will overshoots unless $\frac{d p}{d m}>1$. When the price level increases more than proportional to the change in money stock, it will also increase at a faster pace than the exchange rate and this situation will determine a real exchange appreciation. The foreign price level is assumed fixed in this case. A situation where domestic prices react more than proportional to a given expansionary monetary policy, is not only the contrasting environment to a sticky prices condition, but also the case when prices are more than fully flexible.

Again, to examine the implications of these results we must break down our analysis into two scenarios: high inflation and low inflation. High inflation and hyper inflation go hand in hand with an accelerating velocity of money. This has been a feature observed in every process where prices have grown very rapidly. The higher the velocity of money the higher the inflation level. We may consider velocity of circulation of money as a proxy variable for inflation. When inflation is low, we do not expect velocity to increase we expect velocity to be stable. Usually monetary policy accommodates to GDP growth and prices are not expected to increase as much as money does.

We will expect this over-reaction on the price level (given a monetary expansion) in circumstances of high inflation. Using the simple framework of Cambridge's Quantity Equation, under fixed output and velocity, changes in prices should be proportional to changes in the quantity of money. If output is still fixed and prices increase more than 
proportional to changes in money, it means that velocity of money is increasing very rapidly. This phenomenon is a characteristic of high inflation economies. The opportunity cost of holding money becomes very high and money turns out to be an undesirable asset.

This findings support the hypothesis that under, relatively, high levels of inflation the exchange rate appreciates compared to the classical overshooting model where, under the assumption of sticky prices, the exchange rate exceeds its long term value.

One, condition for the validity of the results presented above is that the expression

$$
\frac{\phi \alpha \kappa-1}{\Gamma}<1
$$

holds for any value of the parameters involved. We can easily prove that (3.34) will always hold.

$$
\begin{aligned}
& \phi \alpha \kappa-1<\Gamma \\
& \phi \alpha \kappa-1<(\lambda \theta+\theta)+\phi \alpha \kappa+\phi \alpha \sigma \theta \\
& -1<(\lambda \theta+\theta)+\phi \alpha \sigma \theta
\end{aligned}
$$

all the coefficients on the right hand side are positive, hence the inequality holds.

As it has been stated, high inflation and hyper inflation go hand in hand with an accelerating velocity of money. This has been a feature observed in every process where prices have grown very rapidly. The higher the velocity of money the higher the inflation level. We may consider velocity of circulation of money as a proxy variable for inflation. There is a third phenomena associated with these two variables: relative price variability or relative price distortion. Velocity and hyper inflation go together with a dislocation of relative prices. Currency substitution, when inflation is not so high, increases the demand 
for foreign exchange originating a depreciation, when inflation peaks relative price distortion gives rise to the appearance of new financial (and no financial) instruments, more profitable than foreign exchange. People deviates their resources towards these new instruments and as a consequence, demand for foreign goes down inducing a lower exchange rate or an overvaluation of domestic currency.

As I said in the introductory chapter of this dissertation, this study was motivated by the hyper inflationary process that took place in Peru during the second half of the 1980's. Currency substitution, although not completely, turned out as a characteristic of this rapid inflation phenomenon. It is more appropriate to consider currency substitution as a feature, instead of a setting where perfect capital mobility equalizes expected net yields and turns out to be the mechanism through which expected devaluation is incorporated to the money demand equation. 


\section{CHAPTER 4 \\ EMPIRICAL ESTIMATES}

\subsection{Introduction}

The results obtained in Chapter 3 determine that, under a monetary expansion, prices will react faster than the exchange rate if prices react more than proportionally to the monetary disturbance. Otherwise, we will observe that the exchange rate depreciates faster than inflation leading to a real exchange appreciation, which is the well-known overshooting result obtained by Dornbusch (1976).

A situation where domestic prices react more than proportional to a given expansionary monetary policy, is not only the contrasting environment to a sticky prices condition, but also the case when prices are more than fully flexible. We will expect this over-reaction in circumstances of high inflation. Using the Quantity Equation also known as the Cambridge equation, under fixed output and velocity, changes in prices should be proportional to changes in the quantity of money. If output is still fixed and prices increase more than proportional to changes in money, it means that velocity of money is increasing very rapidly. This phenomenon is a characteristic of high inflation economies. The opportunity cost of holding money becomes very high and people try to eliminate it from their portfolios.

Within the framework of the Quantity Equation, if velocity is kept constant, a monetary shock will induce a more than proportional change in prices if output declines. In general, very high inflation processes are accompanied by falling output. Peru was not an exception, as hyper inflation went hand in hand with hyper recession. 
One of the characteristics of currency substitution is that people uses foreign exchange as store of value, the nominal return of it is the depreciation rate. When currency substitution is not complete and foreign exchange cannot be used always as medium of exchange there is a transaction cost of converting foreign exchange into domestic currency, which reduces the profitability of the asset. The transaction cost includes not only the time and effort to change the moneys but also the difference between the purchasing price and the selling price (bid-ask spread).

The relationship between velocity of money and exchange rate may be described by the following transmission mechanism: an increase in velocity, associated with higher inflation levels will expand the spread of relative prices, on the extreme case of hyper inflation, this variability leads to the appearance of new financial (and also non-financial) assets, with a higher return than that of foreign exchange. For instance, during the Peruvian hyper inflation, lending on the margin generated the highest return among all financial assets. There were also purchasing programs where the consumer paid a fraction of the real value of a good each month and owned that fraction of the good no matter how the price level changed, when he or she finished paying $100 \%$ of the real value, then he/she received the good. Under currency substitution, economic agents will switch their foreign exchange demand towards these more profitable assets, the decrease in demand for foreign exchange imposes downward pressures on the real exchange rate. Hence, velocity is inversely related to the exchange rate.

The findings in Chapter 3 suggest that hyper inflation is linked to a decrease of the real exchange rate. The key variable is velocity of money which is inversely related to both the nominal and the real exchange rate. This does not mean that given an increase in velocity, the nominal exchange rate will decline, because there are other variables (mainly the price 
level) that push it up. What it means is that the partial influence of velocity on the nominal exchange rate is negative. We expect velocity to be inversely related to the exchange rate. Velocity represent a continuos variable, for growing inflation.

At a glance, it may seem appropriate to include a dummy variable to capture the differences of low and high inflation periods on the exchange rate. We can see that on a graph, the coefficient of a dummy variable would not give us any insight on the problem. The model in Chapter 3, indicates that the variable that makes the difference on the behavior of the exchange rate is velocity, moreover, it tell us the sign of the coefficient: a higher velocity of circulation of money is associated with a real appreciation.

This chapter reports the empirical estimates of the model developed in Chapter 3. One of attributes of that model is that the variables are compared under two different scenarios: the first one, associated with low levels of inflation and the second one, related to rapid or high inflation. It is very likely that the original series of the variables involved in the model are non-stationary, which implies that spurious correlation may arise, if that is the case all statistical inferences become invalid. This problems may be overcome using contemporary techniques for unit root tests and cointegration tests. Even if the series are non-stationary we may obtain reliable inferences about the estimates yield by Ordinary Least Squares (OLS) procedures -provided all series are integrated of the same order- if all the variables are cointegrated.

First we have to make clear that the variable velocity determines by itself two different scenarios: a low inflation one, when we expect velocity to be constant and the second one: a highly inflationary period when we expect velocity to increase rapidly. We may observe that on Figure 4.1. During the first half of 1985 velocity increases which is a period of 
Figure 4.1

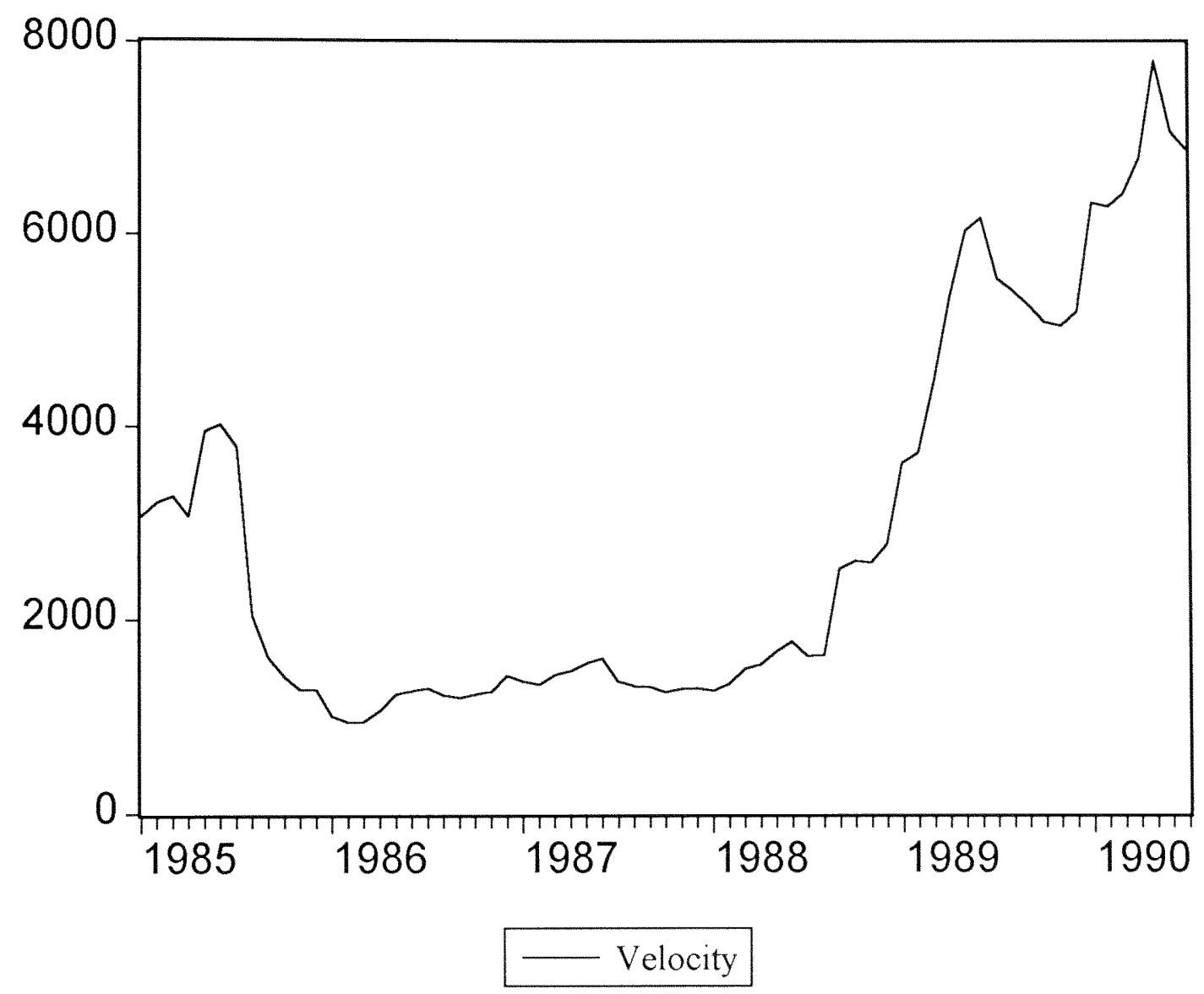


moderate inflation, during the second half of that year velocity decreases responding to a shortening-inflation term. From 1986 through July 1988 velocity is constant. This is the term we identify a relatively low inflation and afterwards it grows quickly. This last period is precisely when hyper inflation took place in Peru.

In order to prove formally that velocity was stable (or constant) during the months we identify inflation being relatively low, the following tests are performed: first it is necessary to compute the coefficient of variation $(\mathrm{CV})$ which assesses the degree of dispersion of a data set relative to its mean.

$$
C V=\frac{s}{\bar{X}} * 100
$$

where $s$ is the sample standard deviation and $\bar{X}$ is the sample mean. The value of CV for the period identified as relatively low inflation is $\mathrm{CV}=15.15 \%$. This value tell us that the variable is stable (Webster 1992), on the other hand the coefficient of variation for the hyper inflationary period is equal to $69.32 \%$. This value corroborates the hypothesis that velocity have been not constant during the hyperinflation process at the end of the decade of the 80's in Peru.

\section{Low inflation}

Since the Coefficient of Variation (CV) is just an indicator, we proceed to perform a formal test. A hypothesis testing procedure is used here to prove that velocity has been stable during the low inflation period.

$$
\begin{aligned}
& H_{0}: \Delta v=0 \\
& H_{A}: \Delta v \neq 0
\end{aligned}
$$


$\Delta \mathrm{v}$ is the rate of growth of velocity. The null hypothesis states that velocity has not changed, while the alternative hypothesis states the opposite. Given that the sample size is relatively large, a Z-test is the appropriate one.

$$
z_{c}=\frac{\overline{\bar{x}}-u}{\frac{s}{\sqrt{n}}}=\frac{0.0209}{\frac{0.1312}{\sqrt{66}}}=1.29
$$

At the $95 \%$ level of confidence the critical value to reject the null hypothesis is $|1.96|$, since $Z_{C}$ does not exceed that value, we do not reject the null hypothesis and conclude that rate of growth of velocity has been equal to zero, hence velocity has been stable.

\section{High inflation}

The same set of hypothesis is claimed here

$$
\begin{aligned}
& H_{0}: \Delta v=0 \\
& H_{A}: \Delta v \neq 0
\end{aligned}
$$

The sample size for this period is smaller, thus appropriate statistic is a t-statistic

$$
\mathrm{t}_{\mathrm{c}}=\frac{\overline{\bar{x}}-\mathrm{u}}{\frac{\mathrm{s}}{\sqrt{\mathrm{n}}}}=\frac{0.0730}{\frac{0.1451}{\sqrt{23}}}=2.413
$$

At the $95 \%$ level of confidence the critical value to reject the null hypothesis is $|2.43|$, since $t_{C}$ does exceed that value, we do reject the null hypothesis and conclude that rate of growth of velocity has been different to zero, hence velocity has not been stable. 
The structure of the chapter is as follows: first, I define the characteristics, sources and the relevant time-period for the data that will be used to run the required regressions. Then, I proceed to perform the unit-root tests and to examine whether the series are stationary or not, for this purpose I will use the augmented Dickey-Fuller test.. The third part of the chapter define a model on the real exchange rate. This model is estimated three times: first

we run the regression for the complete period that goes from January 1985 through July 1990. Then we break it down according to what has been defined as low inflation term, from January 1985 through August 1988. Then, we estimate the hyper inflation period which goes from September 1988 through July 1990.

Cointegration tests are applied to each relevant equation in all models. Multicollinearity and the assumptions of least square estimation are inspected, i.e. no autocorrelation, homoskedasticity etc. Finally, I move on to interpret the results and verify that they are consistent with the conclusions obtained in Chapter 3.

Section 4.5 of this chapter to corroborates that the results obtained also hold for the nominal exchange rate. The model developed in Chapter 3 is based on nominal variables, hence, for the sake of completeness two models are estimated using the nominal exchange rate and the indexes for the domestic and foreign price levels.

\subsection{Data Definitions}

In order to test the model specified in Chapter 3, I have chosen the Peruvian economy which experienced a hyper-inflationary process at the end of the 1980's and went through 
a stabilization process in the early 1990's. The relevant time period goes from January 1985 through July 1990. This period comprises the five-year term in which the APRA party ruled the country. In August 1990, Alberto Fujimori was sworn in as president. He initiated a stabilization program which changed dramatically the ongoing conditions, a strong structural change took place.

The data (monthly) for tests were extracted from the Central Bank weekly and monthly reports, "Peru en Numeros 1992 and 1993" (Peru in figures). Exchange rate is end-ofperiod units of Peruvian currency per US dollar quoted at the parallel market also known as the free market rate. The nominal quantity of money is the narrow definition of money: M1. Real output is the Gross Domestic Product in constant terms, base year 1979. Seasonally adjusted GDP is available for Peru, but it will not be used because hides valuable information. The domestic interest rate is the monthly effective rate for saving deposits. The foreign interest rate is the LIBOR three-months effective rate. The domestic price level is the Consumer Price Index based year 1990. The foreign price level is a weighted average of Consumer Price Indexes of the most important commercial partners of Peru. Velocity of money has been computed following the equation of exchange, i.e. nominal GDP divided by the quantity of money.

Expected devaluation has been obtained through a three months deterministic moving average, which in this case is a limitation given that we do not know the true generating process for expectations. It could have been proxied by the forward premium but Peruvian currency is not quoted in the forward exchange market. 


\subsection{Unit Root Tests for Stationarity}

Prior to testing for cointegration I investigate the time series properties of the individual variables. If the variables are stationary, conventional regression techniques are appropriate. Nevertheless, if the variables are non-stationary with time-dependent means and variances, then, tests of cointegration are necessary to establish long run relationships. If series are non-stationary and they are not cointegrated we can not apply Ordinary Least Squares techniques for estimations because all statistical inferences become invalid.

Individual time series properties are examined using the augmented Dickey-Fuller (ADF) test (Dickey and Fuller 1981). This test may be performed in several manners. Doldado, Jenkinson and Sosvilla-Rivero (1990) suggest a procedure to test for a unit root when the form of the data-generating process is unknown. I use a similar procedure also applied by McNown and Wallace (1994), I started with a relatively long auto regressive structure using twelve lags in the ADF tests. Starting with twelve lags, lags were eliminated three at a time if a conventional t-test showed the lags were insignificant. If insignificant, but omission resulted in serial correlation, the lags were retained. Inclusion of a constant and a trend was, also, conditioned on individually significance given by conventional t-tests. The null hypothesis in the Dickey-Fuller test is the presence of a unit root. A finding favorable to the alternative hypothesis that the data are stationary requires strong evidence against the unit root null.

Test results are shown in Table 1 
Table 1

Variable

ADF

$(\mathrm{T}, \mathrm{L})^{\mathrm{l}}$

Domestic Price level

3.34

$(\mathrm{C}, 1)$

Foreign Price Level

$-2.83^{*}$

$(\mathrm{C}, 1)$

Exchange rate.

5.24

$(\mathrm{N}, 2)$

Domestic Interest Rate

$-2.06$

Foreign Interest Rate

$-2.49$

Nominal Quantity of Money

Real Exchange Rate

4.88

$-1.74$

$(\mathrm{N}, 1)$

$(\mathrm{C}, 0)$

Real Income

$-2.74^{*}$

$(\mathrm{C}, 0)$

Expected Depreciation.

$-2.07$

$(\mathrm{T}, 2)$

Real Domestic Interest Rate -1.91

Real Foreign Interest Rate

$-2.73$

Velocity of Money

$-2.19$

$(\mathrm{C}, 1)$

Residuals $^{2}$

$-2.22$

$(\mathrm{N}, 1)$

All variables are in natural logarithms except from Real Domestic Interest Rate and Real Foreign Interest Rate.

1. $(\mathrm{T}, \mathrm{L})$ the first argument indicates whether a) a trend and a constant have been included: $\mathrm{T}$; b) just a constant: $\mathrm{C}$ or $\mathrm{c}$ ) none of them: $\mathrm{N}$; the second element within the parenthesis indicates the number of lagged difference terms.

2. estimated residuals from....

$* * * * * *$ significant at $0.01,0.05$, and 0.10 respectively

Table 1, shows that the null hypothesis of a unit root is not rejected in most of the cases and might be rejected only at the $90 \%$ level of confidence in two cases: the foreign price level and real income Since we haven been able to reject non stationarity, the next step is to verify whether the series are integrated of order one or I(1). The results of these tests are shown in Table 2 
Table 2

\begin{tabular}{lll}
\hline Variable & ADF & $(\mathrm{T}, \mathrm{L})^{1}$ \\
\hline Domestic Price level & $-4.57^{* * *}$ & $(\mathrm{C}, 0)$ \\
Foreign Price Level & $-6.55^{* * *}$ & $(\mathrm{~T}, 1)$ \\
Exchange rate & $-6.86^{* * *}$ & $(\mathrm{~T}, 0)$ \\
Domestic Interest Rate & $-7.22 * * *$ & $(\mathrm{~T}, 0)$ \\
Foreign Interest Rate & $-6.68^{* * *}$ & $(\mathrm{~N}, 0)$ \\
Nominal Quantity of Money & $-5.19^{* * *}$ & $(\mathrm{~T}, 0)$ \\
Real Exchange Rate & $-7.30^{* * *}$ & $(\mathrm{C}, 0)$ \\
Real Income & $-8.52^{* * *}$ & $(\mathrm{~N}, 0)$ \\
Expected Depreciation. & $-6.42^{* * *}$ & $(\mathrm{~T}, 2)$ \\
Real Domestic Interest Rate & $-7.29^{* * *}$ & $(\mathrm{~N}, 0)$ \\
Real Foreign Interest Rate & $-9.94 * * *$ & $(\mathrm{~N}, 1)$ \\
Velocity of Money & $-6.07 * * *$ & $(\mathrm{~T}, 0)$ \\
Residuals 2 & $-6.05 * * *$ & $(\mathrm{~N}, 0)$
\end{tabular}

All variables are in natural logarithms except from Real Domestic Interest Rate and Real Foreign Interest Rate.

1. $(\mathrm{T}, \mathrm{L})$ the first argument indicates whether a) a trend and a constant have been included: $\mathrm{T}$; b) just a constant: $\mathrm{C}$ or $\mathrm{c}$ ) none of them: $\mathrm{N}$; the second element within the parenthesis indicates the number of lagged difference terms.

2. estimated residuals from.....

$* * *, * *, *$ significant at $0.01,0.05$, and 0.10 respectively

In all the cases we reject the null hypothesis of the series being $I(2)$ in favor of the alternative that states that the series are I(1). In all the cases, the null hypothesis is rejected at the $99 \%$ level of confidence. Note that for half of the variables it was not necessary to include a trend in the unit root test. Given that all the series are integrated of the same order -they are non-stationary but all of them are I(1)- we can now perform the cointegration test for long-run relationship. 


\subsection{A Model on the Real Exchange Rate}

This model pretends to capture the inverse relationship between velocity --income velocity of money-- and the real exchange rate. When velocity of money increases we expect that the exchange rate undershoots. According to what is stated above, we expect a positive relationship between output and the exchange rate. A big recession, under the light of the quantity equation, will determine that prices change more than proportional when reacting to a monetary shock, hence, the exchange rate undershoots.

Following the results obtained in Chapter 3, we proceed to estimate this model in order to verify empirically our findings.

The equation to estimate is:

$$
\varepsilon=f\left(v, y, r, r^{*}\right)
$$

where is the real exchange rate.

$r$ is the logarithm of the domestic interest rate

$r^{*}$ is the logarithm foreign interest rate

$v$ is income velocity of money

$y$ is the logarithm of real income

Table three displays the results of the cointegration test. In order to perform this test the Johansen-Juselius methodology was applied using a linear trend and two lagged differences. 
Table 3 .

Cointegration Test.

Johansen-Juselius Methodology.

Sample: 1985:01 1990:07

Included observations: 64

Test assumption: Linear deterministic trend in the data

Series: $\varepsilon, \boldsymbol{v}, \boldsymbol{y}, r, r^{*}$

Lags interval: 1 to 2

\begin{tabular}{|c|c|c|c|c|}
\hline & Likelihood & 5 Percent & 1 Percent & Hypothesized \\
\hline Eigenvalue & Ratio & Critical Value & Critical Value & No. of $\mathrm{CE}(\mathrm{s})$ \\
\hline 0.446761 & 74.44523 & 68.52 & 76.07 & None $*$ \\
\hline 0.224879 & 36.55949 & 47.21 & 54.46 & At most 1 \\
\hline 0.177543 & 20.25637 & 29.68 & 35.65 & At most 2 \\
\hline 0.105530 & 7.747024 & 15.41 & 20.04 & At most 3 \\
\hline 0.009478 & 0.609482 & 3.76 & 6.65 & At most 4 \\
\hline
\end{tabular}

*(**) denotes rejection of the hypothesis at $5 \%(1 \%)$ significance level

L.R. test indicates 1 cointegrating equation(s) at $5 \%$ significance level

The variables specified in equation (4.1) are non-stationary but they are all integrated of order 1, which means that their first differences are stationary. Table 3 reports the presence of 1 cointegrating equation at the $5 \%$ level of significance. In that sense, it is possible to assert that there is a long run relationship among the variables considered in that equation. Next table reports the estimates of the Ordinary Least Squares procedure, this results are valid because the variables involved, although non-stationary, are cointegrated. 
Table 4.

Ordinary Least Square Estimation // Dependent Variable is $\varepsilon$

Sample: 1985:02 1990:07

Included observations: 66 after adjusting endpoints

Iterative process of Cochrane-Orcutt. Convergence achieved after 5 iterations

\begin{tabular}{lcccc}
\hline Variable & Coefficient & Std. Error & T-Statistic & Prob. \\
$\mathrm{C}$ & 0.116449 & 2.183060 & 0.053342 & 0.9576 \\
$v$ & -0.550777 & 0.178650 & -3.082997 & 0.0031 \\
$y$ & 0.919764 & 0.305282 & 3.012831 & 0.0038 \\
$r$ & 0.070477 & 0.111910 & 0.629767 & 0.5312 \\
$r^{*}$ & 0.643761 & 0.463013 & 1.390371 & 0.1696 \\
AR(1) & 0.846766 & 0.077010 & 10.99556 & 0.0000
\end{tabular}

\begin{tabular}{|c|c|c|c|c|}
\hline R-squared & 0.867888 & Mean dependent var & & 2.572678 \\
\hline Adjusted R-squared & 0.856879 & S.D. dependent var & & 0.433787 \\
\hline S.E. of regression & 0.164108 & Akaike info criterion & & -3.527950 \\
\hline Sum squared resid & 1.615877 & Schwartz criterion & & -3.328890 \\
\hline Log likelihood & 28.77270 & F-statistic & & 78.83206 \\
\hline Durbin-Watson stat & 1.643652 & Prob(F-statistic) & & 0.000000 \\
\hline Inverted AR Roots & .85 & & & \\
\hline \multicolumn{5}{|l|}{ ARCH Test: } \\
\hline F-statistic & 2.021128 & Probability & 0.160056 & \\
\hline Obs*R-squared & 2.020471 & Probability & 0.155191 & \\
\hline \multicolumn{5}{|c|}{ White Heteroskedasticity Test: } \\
\hline F-statistic & 3.423730 & Probability & 0.002790 & \\
\hline Obs*R-squared & 21.42118 & Probability & 0.006109 & \\
\hline
\end{tabular}

The presence of autocorrelation was detected through the Durbin-Watson test, this deficiency was corrected using the Cochrane-Orcutt iterative process designed to deal with problems of serial correlation. Convergence was achieved after five iterations. At the 0.01 significance level, we do not reject the null hypothesis of homoskedasticity. All the 
assumptions underlying OLS estimation have been fulfilled, hence, statistical inferences may be derived.

According to Table 4, neither the domestic interest rate nor the foreign interest rate are significant explaining the variations of the real exchange rate. In other words, their coefficients are not statistically different from zero.

Both interest rates (domestic and foreign) are not relevant explaining the behavior of the endogenous variable, the corresponding $\mathrm{T}$-statistics are very low in absolute value, therefore the null hypothesis $\beta_{i}=0$ cannot be rejected, where $\beta_{i}$ is the coefficient of the $i$ variable (i.e. domestic interest rate and foreign interest rate respectively)

The most important results of equation 4.1 are those related to the variables: incomevelocity of money and Gross Domestic Product. The primary conclusion of the theoretical model developed in Chapter 3, is that undershooting occurs when domestic prices react more than proportionally to a monetary expansion. This situation arises when incomevelocity of money increases and/or income (output level) decreases. So we should expect the exchange rate to be inversely related to velocity and directly related to output. That is exactly what Table 4 reports. At the $99 \%$ level of confidence, we reject the null hypothesis that the coefficient of the variable "income-velocity of money" is equal to zero in favor of the alternative which states the opposite. The sign of this coefficient is negative, thus, velocity is inversely related to the exchange rate. Likewise, results in Table 4 strongly support the direct relationship between the exchange rate and output. This results also concur with the domestic absorption approach, an increase in output increases imports, through the marginal propensity to import, augmenting the demand for foreign exchange inducing a depreciation. 
It can be concluded that Peruvian data shows that undershooting of the exchange rate is strongly associated to an increase in income-velocity of money and/or a situation of recession or falling output.

\section{The Real Exchange Rate under Low Inflation}

Next we proceed to estimate equation 4.1 for the sub-period related to low inflation and constant velocity

\section{Table 5}

Ordinary Least Squares Estimation // Dependent Variable is $\varepsilon$

Sample: 1985:02 1988:08

Included observations: 43 after adjusting endpoints

Iterative process of Cochrane-Orcutt. Convergence achieved after 9 iterations

\begin{tabular}{|c|c|c|c|c|c|}
\hline Variable & Coefficient & Std. Error & T-Statistic & Prob. & \\
\hline$C$ & 3.643503 & 34.33017 & 0.106131 & 0.9161 & \\
\hline$v$ & -0.156397 & 0.158541 & -0.986474 & 0.3303 & \\
\hline$y$ & 0.391601 & 0.242289 & 1.616260 & 0.1145 & \\
\hline $\boldsymbol{r}$ & -0.104550 & 0.092066 & -1.135602 & 0.2634 & \\
\hline$r *$ & 0.717873 & 0.260642 & 2.754253 & 0.0091 & \\
\hline $\operatorname{AR}(1)$ & 0.995112 & 0.050490 & 19.70909 & 0.0000 & \\
\hline not R-squared & \multicolumn{2}{|c|}{0.923910} & \multicolumn{2}{|c|}{ Mean dependent var } & 2.750785 \\
\hline Adjusted R-squ & \multicolumn{2}{|c|}{0.913628} & \multicolumn{2}{|c|}{ S.D. dependent var } & 0.294886 \\
\hline
\end{tabular}


Table 5 (cont.)

$\begin{array}{lclr}\text { S.E. of regression } & 0.086665 & \text { Akaike info criterion } & -4.762630 \\ \text { Sum squared resid } & 0.277898 & \text { Schwartz criterion } & -4.516881 \\ \text { Log likelihood } & 47.38219 & \text { F-statistic } & 89.85322 \\ \text { Durbin-Watson stat } & 1.903445 & \text { Prob(F-statistic) } & 0.000000 \\ \text { Inverted AR Roots } & 1.00 & & \end{array}$

As expected, the coefficient for "velocity" becomes insignificant explaining variations of the real exchange rate. Velocity is a constant variable, and the exchange rate depreciates we can easily predict that a fixed variable may not explain variations on the changing variable. The coefficient for output level weakens here.

\section{The Real Exchange Rate under Hyper Inflation}

Equation 4.1 is run again, now for the term when hyper inflation stroke the Peruvian economy

Table 6.

Ordinary Least Squares Estimation // Dependent Variable is $\varepsilon$

Sample: 1988:09 1990:07

Included observations: 23

Iterative process of Cochrane-Orcutt. Convergence achieved after 11 iterations

Variable Coefficient Std. Error T-Statistic Prob.

$\begin{array}{lllll}\text { C } & 4.811328 & 7.471364 & 0.643969 & 0.5282\end{array}$


Table 6 (cont)

Variable Coefficient Std. Error T-Statistic Prob.

\begin{tabular}{lllll}
\hline$v$ & -1.400076 & 0.532103 & -2.631211 & 0.0175 \\
$y$ & 1.716202 & 1.181997 & 1.451950 & 0.1647 \\
$r$ & 0.139434 & 0.386213 & 0.361029 & 0.7225 \\
$r^{*}$ & -0.349302 & 1.739944 & -0.200755 & 0.8433 \\
$\operatorname{AR}(1)$ & 0.577845 & 0.247007 & 2.339389 & 0.0318
\end{tabular}

R-squared

0.754162

Mean dependent var

2.239696

Adjusted R-squared $\quad 0.681857$

S.D. dependent var

0.460467

S.E. of regression

0.259723

Akaike info criterion

$-2.476823$

Sum squared resid

1.146750

Schwartz criterion

$-2.180608$

Log likelihood

1.847884

F-statistic

10.43026

Durbin-Watson stat

1.537326

Prob(F-statistic)

0.000104

Inverted AR Roots .58

The above results match with those found in Table 4, velocity is inversely related to the real exchange rate and GDP has a direct relationship with it. Those results, however, are more reliable because it enjoys degrees of freedom given that it is a larger sample. 


\subsection{On the Nominal Exchange Rate}

\section{The Basic Model.}

Exchange rate overshooting, the situation where prices change at a faster pace than the exchange rate has been examined in detail by Dornbusch $(1976,1980)$. The explanation for this phenomena is based on the fact that prices in the good's market are sticky or adjust sluggishly relative to asset market prices. The main hypothesis of this dissertation states that under high inflation or hyper inflation the exchange rate undershoots, in other words the general price level will change more rapidly than the exchange rate. The results obtained in Chapter 3 determine that, under a monetary expansion, prices will react faster than the exchange rate if prices react more than proportionally to the monetary disturbance.

The first model on this section pretends to capture the inverse relationship between velocity --income velocity of money-- and the nominal exchange rate. When velocity of money increases we expect that the exchange rate undershoots. According to what is stated above, we expect a positive relationship between output and the exchange rate. A big recession, under the light of the quantity equation, will determine that prices change more than proportional when reacting to a monetary shock, hence, the exchange rate undershoots.

The first equation is:

$$
e=f\left(p, p^{*}, r, v, r^{*}, y\right)
$$


where $r$ is the logarithm of the domestic interest rate

$r^{*}$ is the logarithm foreign interest rate

$e$ is the logarithm of the current exchange rate

$v$ is income velocity of money

$p$ is the logarithm of the price level

$y$ is the logarithm of real income

$p^{*}$ is the logarithm of the foreign price level

\section{Table 7.}

Cointegration Test.

Johansen-Juselius Methodology.

Sample: 1985:01 1990:07

Included observations: 64

Test assumption: Linear deterministic trend in the data

Series: $e, p, p^{*}, r, v, r^{*}, y$

Lags interval: 1 to 2

\begin{tabular}{lllll}
\hline Eigenvalue & $\begin{array}{l}\text { Likelihood } \\
\text { Ratio }\end{array}$ & $\begin{array}{l}\text { 5 Percent } \\
\text { Critical Value }\end{array}$ & $\begin{array}{l}\text { 1 Percent } \\
\text { Critical Value }\end{array}$ & $\begin{array}{l}\text { Hypothesized } \\
\text { No. of CE(s) }\end{array}$ \\
\hline 0.595288 & 179.0251 & 124.24 & 133.57 & None ** \\
0.489350 & 121.1320 & 94.15 & 103.18 & At most $1 * *$ \\
0.341991 & 78.11952 & 68.52 & 76.07 & At most $2^{* *}$ \\
0.291891 & 51.33314 & 47.21 & 54.46 & At most $3 *$ \\
0.178870 & 29.24309 & 29.68 & 35.65 & At most 4 \\
0.160156 & 16.63037 & 15.41 & 20.04 & At most $5^{*}$ \\
0.081772 & 5.459841 & 3.76 & 6.65 & At most $6 *$ \\
& & & & \\
\hline
\end{tabular}

$*(* *)$ denotes rejection of the hypothesis at $5 \%(1 \%)$ significance level

L.R. test indicates 4 cointegrating equation(s) at $5 \%$ significance level 
The variables specified in equation (4.2) are non-stationary but they are all integrated of order 1, which means that their first differences are stationary. Table 7 reports the presence of 4 cointegrating equations at the $5 \%$ level of significance. In that sense, it is possible to assert that there is a long run relationship among the variables considered in that equation. Next table reports the estimates of the Ordinary Least Squares procedure, this results are valid because the variables involved, although non-stationary, are cointegrated.

Table 8

Ordinary Least Square Estimation // Dependent Variable is: $e$ Sample: 1985:02 1990:07

Included observations: 66 after adjusting endpoints

Iterative process of Cochrane-Orcutt. Convergence achieved after 5 iterations

Variable Coefficient Std. Error T-Statistic Prob.

$\begin{array}{lllll}\mathrm{C} & 5.871657 & 8.707159 & 0.674348 & 0.5028 \\ p & 1.038535 & 0.083907 & 12.37728 & 0.0000 \\ p^{*} & 0.033961 & 1.617101 & 0.021001 & 0.9833 \\ r & -0.021833 & 0.140271 & -0.155647 & 0.8769 \\ v & -0.576514 & 0.210482 & -2.739023 & 0.0082 \\ r^{*} & 0.671680 & 0.480746 & 1.397162 & 0.1677 \\ y & 1.038135 & 0.356668 & 2.910646 & 0.0051 \\ \operatorname{AR}(1) & 0.874170 & 0.073146 & 11.95099 & 0.0000\end{array}$

\begin{tabular}{lllr}
\hline R-squared & 0.996850 & Mean dependent var & 5.219238 \\
Adjusted R-squared & 0.996469 & S.D. dependent var & 2.783019 \\
S.E. of regression & 0.165363 & Akaike info criterion & -3.486009 \\
Sum squared resid & 1.586010 & Schwartz criterion & -3.220596 \\
Log likelihood & 29.38835 & F-statistic & 2621.798 \\
Durbin-Watson stat & 1.646739 & Prob(F-statistic) & 0.000000 \\
\hline
\end{tabular}

Table 8 (cont.) 
ARCH Test:

F-statistic

2.350257

Probability

0.130269

Obs*R-squared

2.337661

Probability

0.126279

White Heteroskedasticity Test:

F-statistic

2.387123

Probability

0.015108

Obs*R-squared

23.15623

Probability

0.026429

The presence of autocorrelation was detected through the Durbin-Watson test, this deficiency was corrected using the Cochrane-Orcutt iterative process designed to deal with problems of serial correlation. Convergence was achieved after five iterations. At the 0.01 significance level, we do not reject the null hypothesis of homoskedasticity. All the assumptions underlying OLS estimation have been fulfilled, hence, statistical inferences may be derived.

The foreign price level and both interest rates (domestic and foreign) are not relevant explaining the behavior of the endogenous variable, the corresponding T-statistics are very low in absolute value, therefore the null hypothesis $\beta_{i}=0$ cannot be rejected, where $\beta_{i}$ is the coefficient of the $i$ variable (i.e. foreign price level, domestic interest rate and foreign interest rate respectively). It happens that in all three cases the signs of the coefficients are not the expected ones, however, this is not a cause for concern because, as it has been said, those coefficients are not statistically different from zero.

The most important results of equation 4.2 are those related to the variables: incomevelocity of money and Gross Domestic Product. The primary conclusion of the theoretical model developed in Chapter 3, is that undershooting occurs when domestic prices react more than proportionally to a monetary expansion. This situation arises when incomevelocity of money increases and/or income (output level) decreases. So we should expect 
the exchange rate to be inversely related to velocity and directly related to output. That is exactly what Table 4 reports. At the $99 \%$ level of confidence, we reject the null hypothesis that the coefficient of the variable "income-velocity of money" is equal to zero in favor of the alternative which states the opposite. The sign of this coefficient is negative, thus, velocity is inversely related to the exchange rate. Likewise, results in Table 8 strongly support the direct relationship between the exchange rate and output. This results also concur with the domestic absorption approach, an increase in output increases imports, through the marginal propensity to import, augmenting the demand for foreign exchange inducing a depreciation.

The coefficient for the domestic price level, also included in equation 4.2, shows a strong T-statistic and displays the positive relationship between this variable and the exchange rate, as is stated on the Purchasing Power Parity theory. There is potential problem, the price level the variable may not be that determines the exchange rate but it may be the exchange rate the one which drives and moves the price level. This problem is considered in the following sections of this chapter.

\subsubsection{An Instrumental Variable}

This section reformulates the basic model in such a way that the influence of the exchange rate on the price level is filtered or separated.

The relevant equation is:

$$
e=f\left(s, p^{*}, x, v, r, y\right)
$$

where $s$ is the series of the residuals from the equation::

$$
p=f\left(e_{t}, e_{t-1}, \ldots, e_{t-12}\right)
$$


i.e. the price level is regressed on the current exchange rate and its twelve lags.

$x$ is the expected rate of depreciation, it is a three-month deterministic moving average.

Equation (4.3) contemplates two changes with respect to equation (4.2) The original model included the price level, $p$, as one of the determinants of the exchange rate. If the exchange rate has an influence on the price level, the dependent variable influences one of the independent variables; this violates the assumptions of OLS estimation. Estimating the residuals of equation (4.4) yields a series that represents the price level filtered of the influence of the exchange rate, see Himarios (1993). This new variable named " $s$ " replaces the price level $p$.

In a context of currency substitution and no capital mobility the world interest rate becomes irrelevant. The expected rate of depreciation, in turn, emerges in the money demand function as the opportunity cost of holding money, and impacts the exchange rate. The foreign interest rate is replaced by the expected rate of depreciation labeled $x$.

Table 9.

Cointegration Test.

Johansen-Juselius Methodology.

Sample: 1985:01 1990:07

Included observations: 54

Test assumption: Linear deterministic trend in the data

Series: $e, s, p^{*}, x, v, r, y$

Lags interval: 1 to 2

\begin{tabular}{lllll}
\hline Eigenvalue & $\begin{array}{l}\text { Likelihood } \\
\text { Ratio }\end{array}$ & $\begin{array}{l}\text { 5 Percent } \\
\text { Critical Value }\end{array}$ & $\begin{array}{l}\text { 1 Percent } \\
\text { Critical Value }\end{array}$ & $\begin{array}{l}\text { Hypothesized } \\
\text { No. of CE(s) }\end{array}$ \\
\hline 0.892880 & 244.1094 & 124.24 & 133.57 & None $* *$ \\
0.529345 & 123.4838 & 94.15 & 103.18 & At most $1 * *$ \\
0.454660 & 82.78777 & 68.52 & 76.07 & At most $2 * *$
\end{tabular}


Table 9 (cont.)

\begin{tabular}{lllll}
\hline 0.346557 & 50.04508 & 47.21 & 54.46 & At most $3 *$ \\
0.239375 & 27.06808 & 29.68 & 35.65 & At most 4 \\
0.150709 & 12.29292 & 15.41 & 20.04 & At most 5 \\
0.062270 & 3.471862 & 3.76 & 6.65 & At most 6
\end{tabular}

$*(* *)$ denotes rejection of the hypothesis at $5 \%(1 \%)$ significance level

L.R. test indicates 4 cointegrating equation(s) at 5\% significance level

As before, given that the variables are cointegrated, I proceed to estimate equation 4.3. The results are summarized in Table 10. where, again, the presence of autocorrelation was detected through the Durbin-Watson test, this deficiency was corrected using the Cochrane-Orcutt iterative process designed to deal with problems of serial correlation. Convergence was achieved after twelve iterations.

Table 10.

Ordinary Least Squares Estimation // Dependent Variable is $e$

Sample: 1985:12 1990:07

Included observations: 56 after adjusting endpoints

Convergence achieved after 12 iterations

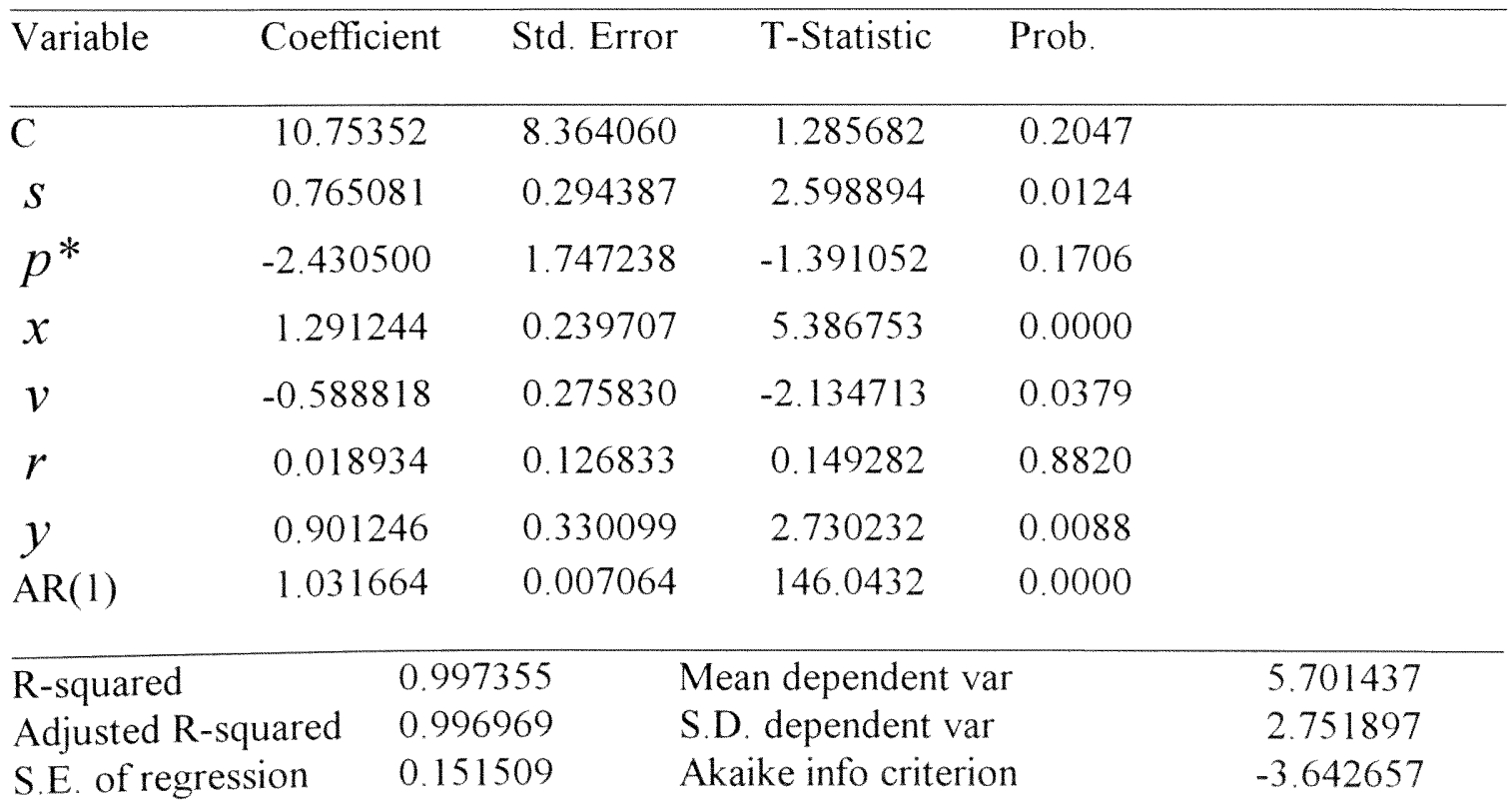


Table 10 (cont.)

\begin{tabular}{lclc}
\hline Sum squared resid & 1.101839 & Schwartz criterion & -3.353321 \\
Log likelihood & 30.53383 & F-statistic & 2585.245 \\
Durbin-Watson stat & 1.858215 & Prob(F-statistic) & 0.000000 \\
Inverted AR Roots & 1.03 & & \\
Estimated AR process is non stationary &
\end{tabular}

ARCH Test:

$\begin{array}{llll}\text { F-statistic } & 0.081904 & \text { Probability } & 0.775850 \\ \text { Obs*R-squared } & 0.084863 & \text { Probability } & 0.770812\end{array}$

White Heteroskedasticity Test:

$\begin{array}{llll}\text { F-statistic } & 1.156362 & \text { Probability } & 0.343568 \\ \text { Obs*R-squared } & 13.66254 & \text { Probability } & 0.322775\end{array}$

At the 0.01 significance level, we do not reject the null hypothesis of homoskedasticity. All the assumptions underlying OLS estimation have been fulfilled, hence, statistical inferences may be derived.

As before, the foreign price level and domestic interest rates are not relevant explaining the behavior of the endogenous variable, the corresponding T-statistics are very low in absolute value, therefore the null hypothesis $\beta_{i}=0$ cannot be rejected, where $\beta_{i}$ is the coefficient of the $i$ variable ( i.e. foreign price level and domestic interest rate respectively). It happens that in both cases the signs of the coefficients are not the expected ones, however, this is not a cause for concern because, as it has been said, those coefficients are not statistically different from zero.

Individual tests for the coefficients of the two key variables, velocity and output, lead to the rejection of the null hypothesis of non-significance. The signs of the coefficients are 
the same obtained in Table 8, where equation 4.2 was estimated. The conclusions of the model in Chapter 3 are also confirmed by the estimates of equation 4.3 .

Expected devaluation is positively related to the exchange rate, as expected. The coefficient of the residuals, $s$, used as a proxy for the domestic price level is positive and significant at the $95 \%$ level of confidence. The T-statistic indicator is much lower than the one related to the price level in Table 8 , which, in a sense, implies that effect of the exchange rate on the price level has been successfully filtered.

\subsubsection{Dropping the Domestic Interest Rate}

Equation (4.4) becomes:

$$
e=f\left(s, p^{*}, x, v, y\right)
$$

$\mathrm{r}$ was not relevant an the sign was twisted, also might be a cause for multicollinearity.

Table 11 .

Cointegration Test.

Johansen-Juselius Methodology.

Sample: 1985:01 1990:07

Included observations: 54

Test assumption: Linear deterministic trend in the data

Series: $e, s, p^{*}, x, v, y$

Lags interval: 1 to 2

$\begin{array}{cllll} & \text { Likelihood } & \text { 5 Percent } & \text { 1 Percent } & \text { Hypothesized } \\ \text { Eigenvalue } & \text { Ratio } & \text { Critical Value } & \text { Critical Value } & \text { No. of CE(s) } \\ 0.887390 & 204.8889 & 94.15 & 103.18 & \text { None }\end{array}$


Table 11. (cont.)

\begin{tabular}{ccccc}
\hline 0.497050 & 86.96251 & 68.52 & 76.07 & At most $1^{* *}$ \\
0.303256 & 49.85026 & 47.21 & 54.46 & At most $2^{*}$ \\
0.260256 & 30.33808 & 29.68 & 35.65 & At most $3^{*}$ \\
0.173892 & 14.05970 & 15.41 & 20.04 & At most 4 \\
0.066986 & 3.744105 & 3.76 & 6.65 & At most 5
\end{tabular}

${ }^{*}(* *)$ denotes rejection of the hypothesis at $5 \%(1 \%)$ significance level L.R. test indicates 4 cointegrating equation(s) at $5 \%$ significance level

Table 12 .

Ordinary Least Square Estimation // Dependent Variable is: $e$

Sample: 1985:12 1990:07

Included observations: 56 after adjusting endpoints

Convergence achieved after 18 iterations

\begin{tabular}{lllrl}
\hline Variable & Coefficient & Std. Error & T-Statistic & Prob. \\
$\mathrm{C}$ & 10.47162 & 8.070980 & 1.297441 & 0.2006 \\
$s$ & 0.767390 & 0.291013 & 2.636963 & 0.0112 \\
$p^{*}$ & -2.392315 & 1.712344 & -1.397100 & 0.1687 \\
$x$ & 1.289950 & 0.237157 & 5.439234 & 0.0000 \\
$v$ & -0.584904 & 0.271858 & -2.151502 & 0.0364 \\
$y$ & 0.911624 & 0.319374 & 2.854407 & 0.0063 \\
AR(1) & 1.031597 & 0.006931 & 148.8416 & 0.0000 \\
\hline
\end{tabular}

$\begin{array}{lcll}\text { R-squared } & 0.997353 & \text { Mean dependent var } & 5.701437 \\ \text { Adjusted R-squared } & 0.997029 & \text { S.D. dependent var } & 2.751897 \\ \text { S.E. of regression } & 0.149990 & \text { Akaike info criterion } & -3.677907 \\ \text { Sum squared resid } & 1.102351 & \text { Schwartz criterion } & -3.424738 \\ \text { Log likelihood } & 30.52083 & \text { F-statistic } & 3077.523 \\ \text { Durbin-Watson stat } & 1.834278 & \text { Prob(F-statistic) } & 0.000000 \\ \text { Inverted AR Roots } & 1.03 & & \end{array}$

Estimated AR process is non stationary

\begin{tabular}{llll}
\hline ARCH Test: & & & \\
F-statistic & 0.088283 & Probability & 0.767533 \\
Obs*R-squared & 0.091462 & Probability & 0.762327
\end{tabular}


Table 12. (cont.)

White Heteroskedasticity Test:

$\begin{array}{llll}\text { F-statistic } & 1.207671 & \text { Probability } & 0.311956 \\ \text { Obs*R-squared } & 11.84890 & \text { Probability } & 0.295297\end{array}$

The findings presented in Table 12 do not differ substantially from what has been verified on Table 10. Nevertheless, it is important to point out that equation 4.5 is useful to rule out any presumption of multicollinearity given that the Pearson correlation coefficient between the domestic interest rate and the income-velocity of money is 0.94 .

\subsubsection{A Simultaneous Equation System}

Another way to deal with the identification problem stated above is to design a simultaneous equation system. Equations (4.6) and (4.7) conform our system.

$$
\begin{aligned}
& e=f\left(r, p^{*}, v, x, y, p\right) \\
& p=f(m, y, e)
\end{aligned}
$$

where $m$ is the logarithm of the nominal quantity of money.

A Two-Stage Least Squares procedure is used to run simultaneously both equations. The first stage will run the price level against all the variables included in the model and compute the corresponding fitted values. Those fitted values are used in the second stage, replacing the original series of the price level. 
Table 13

Cointegration Test.

Johansen-Juselius Methodology.

Sample: 1985:01 1990:07

Included observations: 64

Test assumption: Linear deterministic trend in the data

Series: $e, r, p^{*}, v, x, y, p$

Lags interval: 1 to 2

Table 13 (cont.)

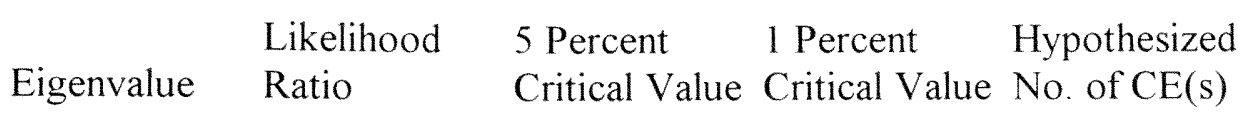

\begin{tabular}{lcccc}
\hline 0.866516 & 256.2777 & 124.24 & 133.57 & None $* *$ \\
0.421401 & 127.3962 & 94.15 & 103.18 & At most $1 * *$ \\
0.400982 & 92.37882 & 68.52 & 76.07 & At most $2 * *$ \\
0.271346 & 59.58114 & 47.21 & 54.46 & At most $3 * *$ \\
0.255226 & 39.32155 & 29.68 & 35.65 & At most $4 * *$ \\
0.209039 & 20.46236 & 15.41 & 20.04 & At most $5^{* *}$ \\
0.081687 & 5.453918 & 3.76 & 6.65 & At most $6 *$ \\
\hline
\end{tabular}

$\left.*^{* *}\right)$ denotes rejection of the hypothesis at $5 \%(1 \%)$ significance level

L.R. test indicates 7 cointegrating equation(s) at 5\% significance level

Table 14.

Two Stage Least Square Estimation // Dependent Variable is: $e$

Sample: 1985:02 1990:07

Included observations: 66 after adjusting endpoints

Convergence achieved after 16 iterations

Instrument list: $r, m, y, p^{*}, v, x$,

\begin{tabular}{lcccc}
\hline Variable & Coefficient & Std. Error & T-Statistic & Prob. \\
$\mathrm{C}$ & 10.69205 & 7.157502 & 1.493824 & 0.1406 \\
$r$ & -0.030521 & 0.105031 & -0.290587 & 0.7724
\end{tabular}


Table 14 (cont.)

\begin{tabular}{lrrrr}
\hline$p^{*}$ & -0.708820 & 1.368681 & -0.517885 & 0.6065 \\
$v$ & -0.654733 & 0.163872 & -3.995403 & 0.0002 \\
$x$ & 1.300216 & 0.212546 & 6.117341 & 0.0000 \\
$y$ & 1.119431 & 0.277663 & 4.031610 & 0.0002 \\
$p$ & 1.013180 & 0.067496 & 15.01090 & 0.0000 \\
AR(1) & 0.906006 & 0.060714 & 14.92249 & 0.0000
\end{tabular}

\begin{tabular}{llll}
\hline R-squared & 0.998057 & Mean dependent var & 5.219238 \\
Adjusted R-squared & 0.997822 & S.D. dependent var & 2.783019 \\
Table 14 (cont.) & & &
\end{tabular}

\begin{tabular}{lclc}
\hline S.E. of regression & 0.129870 & Akaike info criterion & -3.969225 \\
Sum squared resid & 0.978246 & Schwartz criterion & -3.703812 \\
& & & 2.144141 \\
\hline F-statistic & 4255.815 & Durbin-Watson stat & \\
Prob(F-statistic) & 0.000000 & & \\
Inverted AR Roots & .91 & & \\
& & &
\end{tabular}

\begin{tabular}{lcll}
\hline ARCH Test: & & & \\
F-statistic & 0.555921 & Probability & 0.458681 \\
Obs*R-squared & 0.568552 & Probability & 0.450835 \\
White Heteroskedasticity Test: & & \\
F-statistic & 1.835177 & Probability & 0.065788 \\
Obs*R-squared & 19.37376 & Probability & 0.079899 \\
\hline
\end{tabular}

Autocorrelation was corrected using the Cochrane-Orcutt iterative process designed to deal with problems of serial correlation. All the assumptions underlying OLS estimation have been fulfilled, hence, statistical inferences may be derived.

Once again the foreign price level and domestic interest rates are not relevant explaining the behavior of the endogenous variable. The sign of the coefficient for the interest rate is not the expected one, however, this is not a cause for concern because, as it has been said, that coefficient is not statistically different from zero. 
It is important to highlight the robustness of the results display in Table 14. At the 0.001 significance level we reject the null hypothesis that the coefficients --for velocity, output, expected devaluation and the price level-- are equal to zero. The associated signs are the ones our model predicts. 


\section{CHAPTER 5 \\ CONCLUSIONS}

In this dissertation I examined the behavior of the exchange rate comparing two different scenarios. The first one, characterized by relatively low inflation and the second one by a high inflation economy. In the first one, as a response to a monetary shock, the exchange rate overshoots, i.e. the nominal exchange rate depreciates at a faster pace than the price level. Under high levels of inflation, prices change faster than the depreciation rate , hence the exchange rate undershoots its long run equilibrium value. The purpose of this study was to determine the conditions that lead to the undershooting of the exchange rate, also known as overvaluation.

Dornbusch (1976), explained very well the characteristics under which the exchange rate overshoots. They may be summarized by two special features: 1) prices in the asset's market adjust instantaneously while 2) prices in the good's market are sticky. A monetary expansion -given sticky prices- generates excess supply in the money market, with fixed

output the interest rate goes down. Equalization of net yields internationally would require the expectation of an appreciation so that the spot exchange rate increases beyond its long run equilibrium value. This dissertation expanded on Dornbusch's model and provided an analysis of the exchange rate under conditions of currency substitution and price flexibility, characteristics of the Peruvian economy during the hyper inflation process that took place at the end of the decade of the 1980's.

This dissertation extends previous work in two main aspects: the first one relates to the fact that no one has considered hyper inflation as the qualitative source of exchange rate appreciation and ultimately overvaluation. The second is the incorporation of currency 
substitution into Dornbusch's framework and also the relaxation of the assumption of price rigidity for the short run. Hyper inflation disturbs the stability of some coefficients such as the marginal propensity to consume, income elasticity of money demand, the degree of awareness of relative price variation, the speed of adjustment of expected devaluation among others.

One of the main results of this study is derived from Equation (3.30) in Chapter 3, which tell us how far the spot exchange rate is from its long run equilibrium value for a given change in the price level. It depends on the sign of the term outlined in Equation (3.31) whether undershooting or overshooting occurs. When hyper inflation hits the economy, velocity of money increases very rapidly, economic agents spend all their income almost immediately in order to avoid paying the inflation tax that might deteriorate completely the purchasing power of their wages or salaries. If possible, they materialize immediately all their programmed purchases of the month on the day they receive their salaries. We may interpret this as if the marginal propensity to consume goes to one.

From Equation (3.30) we derived algebraically that as marginal propensity to consume goes to one the exchange rate becomes overvalued. The spot exchange rate will lie below its long run equilibrium. We can also assert that the higher the inflation rate, the larger is the gap $(\bar{e}-e)$. Currency substitution, here, is important to explain how people modify their portfolios and switch from foreign exchange to consumption goods, reducing in this way the demand for foreign currency and therefore its price. Note that under complete indexation, there is no reason why we should expect a change in relative prices nor a change in the marginal propensity to consume. Peoples portfolios will remain unchanged and undershooting will not happen. 
The effects of a monetary expansion were analyzed, and I compared the change in the price level to that of the exchange rate. The conclusion is that whenever the price level increases more than proportional to the change in money stock, it will also increase at a faster pace than the exchange rate and this situation will determine a real exchange appreciation. A situation where domestic prices react more than proportional to a given expansionary monetary policy, is not only the contrasting environment to a sticky prices condition, but also the case when prices are more than fully flexible.

Again, to examine the implications of these results we broke down our analysis into two scenarios: high inflation and low inflation. Hyper inflation goes hand in hand with accelerating velocity of money. This has been a feature observed in every process where prices have grown very rapidly. The higher the velocity of money the higher the inflation level. We may consider velocity of circulation of money as a proxy variable for inflation. When inflation is low, we do not expect velocity to increase, usually monetary policy accommodates to GDP growth and prices are not expected to increase as much as money does. This model does not provide a cutting point in quantitative terms to distinguish low inflation from high inflation. For econometrics purposes, we have used September 1988 as the beginning of hyper inflation following Kiguel and Liviatan (1992).

We will expect this over-reaction on the price level (given a monetary expansion) in circumstances of high inflation. Using the simple framework of Cambridge's Quantity Equation, under fixed output and velocity, changes in prices should be proportional to changes in the quantity of money. If output is still fixed and prices increase more than proportional to changes in money, it means that velocity of money is increasing very rapidly. This phenomenon is a characteristic of high inflation economies. 
This findings support the hypothesis that under, relatively, high levels of inflation the exchange rate appreciates compared to the classical overshooting model where, under the assumption of sticky prices, the exchange rate exceeds its long term value. Again, using the setting of the Quantity Equation, if velocity is kept constant, a monetary shock will induce a more than proportional change in prices if output declines. In general, very high inflation processes are accompanied by falling output. Peru was not an exception, it has been said that hyper inflation went hand in hand with hyper recession. If velocity is not constant but increasing, then falling output will reinforce the effect of escalating velocity.

One of the characteristics of currency substitution is that people uses foreign exchange as store of value, the nominal return of it is the depreciation rate. When currency substitution is not complete and foreign exchange cannot be used always as medium of exchange there is a transaction cost of converting foreign exchange into domestic currency, which reduces the profitability of the asset. The transaction cost includes not only the time and effort to change the moneys but also the difference between the purchasing price and the selling price (bid-ask spread).

The relationship between velocity of money and exchange rate may be described by the following transmission mechanism: an increase in velocity, associated with higher inflation levels will expand the spread of relative prices, on the extreme case of hyper inflation, this variability leads to the appearance of new financial (and also non-financial) assets, with a higher return than that of foreign exchange. Under currency substitution, economic agents will switch their foreign exchange demand towards these more profitable assets, the decrease in demand for foreign exchange imposes downward pressures on the exchange rate. Hence, velocity is inversely related to the exchange rate. 
The findings in Chapter 3 suggest that hyper inflation is linked to a decrease of the real exchange rate. The model uses nominal variables, and I arrived to the conclusion of real exchange appreciation -for high inflation economies- analyzing the evolution of nominal variables. Velocity of money is inversely related to the exchange rate, it is inversely related to both the nominal and the real exchange rate. This does not mean that given an increase in velocity, the nominal exchange rate will decline, because there are other variables (mainly the price level) that push it up. What it means is that the partial influence of velocity on the nominal exchange rate is negative. We expect velocity to be inversely related to the exchange rate. Velocity represent a continuos variable, for growing inflation.

Chapter 4 reports the empirical estimates of the model developed in Chapter 3. I used Peruvian data from January 1985 through July 1990. Given the volatility of the time series included in the regression model, unit root tests were performed to test for stationarity. I found that all variables were integrated of order one and at least one cointegrating vector existed for every equation

The most important results are those related to the variables: income-velocity of money and Gross Domestic Product. The primary conclusion of the theoretical model developed in Chapter 3, was that undershooting occurs when domestic prices react more than proportionally to a monetary expansion. This situation arises when income-velocity of money increases and/or income (output level) decreases. I found the exchange rate inversely related to velocity and directly related to output. At the $99 \%$ level of confidence, I rejected the null hypothesis that the coefficient of the variable "income-velocity of money" is equal to zero in favor of the alternative which states the opposite. The sign of this coefficient is negative, thus, velocity is inversely related to the exchange rate. Likewise, results in Table 4 of Chapter 4 , strongly support the direct relationship between 
the exchange rate and output. This results also concur with the domestic absorption approach, an increase in output increases imports, through the marginal propensity to import, augmenting the demand for foreign exchange inducing a depreciation.

The currency substitution environment, called for a change in first (estimated) model. The international interest rate was replaced by expected devaluation. Prices were eliminated from the regression equation and the real exchange rate was used as the dependent variable. The regression output validated the incorporation of the expected exchange rate in the model. It improved the global significance of the model. The regression coefficients for velocity and output did not change significantly. It can be concluded that Peruvian data shows that undershooting of the exchange rate is strongly associated to an increase in income-velocity of money and/or a situation of recession or falling output. 


\section{LIST OF REFERENCES}

Abusada R. 1987 " Final Report on the Evaluation of AID Project no 527-0244 Development of the Alto Huallaga Area. Lima: ECONSULT S. A.

Allen, Polly Reynolds. 1995. "The Economic and Policy Implications of the NATREX Approach" In J.L Stein, P.R. Allen and Assoc. Fundamental Determinants of Exchange Rates. pp. 1-37. Clarendon Pres. Oxford.

Angenor, Pierre-Richard. "Credibility and Exchange Rate Management in Developing Countries" Journal of Development Economics Vol. 45, (1994), pp. 1-16.

Artus, Jacques. 1977. "Methods of assessing the Long Run Equilibrium Value of an exchange rate", Working Paper No DM/77/124. Washington. International Monetary Fund December.

Baillie, Richard T., and David D. Selover. "Cointegration and Models of Exchange Rate Determination." International Journal of Forecasting 3 (1987), 43-51.

Banco Central de Reserva del Peru. 1986, Memoria 1985. Lima BCRP

Banco Central de Reserva del Peru. 1987. Memoria 1986. Lima BCRP

Banco Central de Reserva del Peru. 1988. Memoria 1987. Lima BCRP

Banco Central de Reserva del Peru. 1989. Memoria 1988. Lima BCRP

Banco Central de Reserva del Peru. 1990. Memoria 1989. Lima BCRP

Banco Central de Reserva del Peru. 1985-1990. Weekly Report. Various Numbers. Lima BCRP

Branson, William H., Asset Markets and Relative Prices in Exchange rate Determination. Reprints in International Finance, No 20 ( Princeton, New Jersey: Princeton University Press, June 1980); reprinted from Sozialwissenschaftliche Anmalen, Band 1 (1977)

Branson, William H., "Macroeconomics Determinants of Real Exchange Risk, " in Managing Foreign Exchange Risk, ed. by Richard J. Herring (Cambridge; New York: Cambridge University Press, 1983)

Branson, William H., " Exchange Rate Policy after a Decade of Floating," in Exchange Rate Theory and Practice, ed. by John F.O. Bilson and Richard C. Marston. (Chicago: Chicago University Press, 1984) 
Bruno, Michael and Sylvia Piterman. 1988. "Israel's Stabilization: A Two Year Review" in eds. Michael Bruno, Stanley Fisher, Rudiger Dornbusch \& Guido Di Tella. "Inflation and Stabilization" The MIT Press.

Buiter, Willem $\mathrm{H}$ and Marcus Miller "Real Exchange Rate Overshooting and the Output Cost of Bringing Down Inflation" European Economic Review Vol. $18 \mathrm{~N}^{\circ} 4$ (1982), pp. $85-123$

Buiter, Willem $\mathrm{H}$ and Marcus Miller "Monetary Policy and International Competitiveness: The Problems of Adjustment" Oxford Economic Papers, Supplement on the Money Supply and the Exchange Rate, ed. by W.A. Eltis and P.J.N. Sinclair, Vol. 33 (July 1981), pp. 143-75.

Cagan. Philip. 1956 "The Monetary Dynamics of Hyper Inflation" in Milton Friedman Editor, Studies in the Quantity Theory of Money, Chicago: University of Chicago Press.

Calvo, Guillermo A. and Rodriguez, Carlos. 1977. "A Model of Exchange Rate Determination under Currency Substitution and Rational Expectations," Journal of Political Economy, Vol. 85, No. 3, 617-625.

Calvo, Guillermo A. and Carlos A. Végh . 1993. "Currency Substitution in High Inflation Countries," Finance and Development, March 1993 34-37.

Cassel, Gustav. 1918. "Abnormal Deviations in International Exchanges" Economic Journal. December.

Cassel, Gustav. 1928. "Post War Monetary Stabilization". Columbia University Press.

Cukierman, Alex. 1988. "The End of High Israeli Inflation: An Experiment in Heterodox Stabilization" in eds. Michael Bruno, Stanley Fisher, Rudiger Dornbusch \& Guido Di Tella. "Inflation and Stabilization" The MIT Press.

DeJong, Eelke. "Exchange Rate Determination and Optimal Economic Policy Under Various Exchange Rate Regimes." in M. Beckmann and W. Krelle editors. Lecture Notes in Economics and Mathematical Systems 359. New York, Springer-Verlag. 1991

Di Tella, Guido. 1979. "Price Oscillation, Oligopolistic Behavior and inflation: The Argentina Case", World Development

Di Tella, Guido. 1988. "Inflation Stabilization or Hyper Inflation Avoidance? The Case of the Austral Plan in Argentina, 1985-87." in eds. Michael Bruno, Stanley Fisher, Rudiger Dornbusch \& Guido Di Tella. "Inflation and Stabilization" The MIT Press. 
Doldado, Juan, Tim Jenkinson, and Simon Sosvilla-Rivero. "Cointegration and Unit Roots." Journal of Economic Surveys 4 (1990),249-73

Dornbusch, Rudiger, and Sebastian Edwards, 1990 "Macroeconomic Populism in Latin America," Journal of Development Economics, 32, No.2, pp. 247-77.

Dornbusch, Rudiger, and Stanley Fisher, "Exchange rates and Current Accounts," American Economic Review, Vol. 71 (December 1980), pp. 960-71.

Dornbusch, Rudiger, 1988. " Balance of Payments Tools" in "The Open Economy: Tools for Policymakers in Developing Countries" eds. Rudiger Dornbusch and F Leslie C.H. Helmers. Oxford University Press.

Dornbusch, R. "Expectations and Exchange Rate Dynamics" Journal of Political Economy, 84 (1976), 1161-76

Driskill, Robert and Stephen McCaferty, "Exchange Rate Determination: An Equilibrium Approach with Imperfect Capital Mobility," Journal of International Economics, November, 1987, 241-261.

Engel, Charles. 1989. "The Trade Balance and the Real Exchange Rate under Currency Substitution," Journal of International Money and Finance, 8 47-58.

Fanelli, Jose Maria and Jose Luis Machinea, 1988. "Stopping Hyper Inflation: The Case of the Austral Plan in Argentina, 1985-87." in eds. Michael Bruno, Stanley Fisher, Rudiger Dornbusch \& Guido Di Tella. "Inflation and Stabilization" The MIT Press.

Frankel, Jeffrey A., " On the Mark: A Theory of Floating Exchange Rate Based on Real Interest Differential," American Economic Review, Vol. 69 (September 1979), pp. 610-22

Frenkel, Jacob A. "The Collapse of Purchasing Power Parity During the 1970s". European Economic Review, 16 (1981), 145-65.

Frenkel, Jacob A. and Carlos Alfredo Rodriguez, 1982. International Monetary Fund. Staff Papers 29, 1-30.

Genberg, H. "Purchasing Power Parity Under Fixed and Flexible Exchange Rates". Journal of International Economics 8, (1978), 247-76.

Glen, Jack D. "Real Exchange Rates in the Short, Medium and Long Run". Journal of International Economics 33, (1992), 147-66.

Hamilton, James D. "Time Series Analysis." New Jersey: Princeton University Press. 1994. 
Himarios, Daniel. 1993. "The Exchange Rate and the US. Wage Process: An Intensive Empirical Investigation" Journal of Money, Credit and Banking Vol. 25, No 1, February

International Monetary Fund. 1984. "Issues in the Assessment of the exchange rates of Industrial Countries" Occasional Paper No 29 Washington. International Monetary Fund

Isard, Peter, "Expected and Unexpected Changes in Exchanges rates: The Roles of Relative Price Levels, Balance of Payments Factors, Interest Rates, and Risk," International Finance Discussion Papers, No 156 (Washington: Board of Governors of the Federal Reserve System, 1983).

Johnson, O.E.G. "The Exchange Rate as an Instrument of Policy a Developing Country." IMF Staff Papers, Vol. 23, No 2, (July 1976), pp. 335-45.

Kelley, Bruce. "Devaluation and Heterodox Policy in Peru." Journal of Developing Areas. October 1996 (forthcoming).

Kiguel, Miguel A. "Exchange Rate Policy, the Real Exchange Rate, and Inflation." Cuadernos de Economia Vol. 31, No 93 (Aug. 1994), pp. 229-249.

Kiguel, Miguel A. and Nissan Liviatan..1992 "The Inflation-Stabilization Cycles in Argentina and Brazil" in eds. Michael Bruno, Stanley Fisher, Elhanan Helpman and Nissan Liviatan. "Lessons from Economic Stabilization and Its Aftermath" The MIT Press.

Kiguel, Miguel A. and Nissan Liviatan. 1992. "Stopping Three Big Inflations (Argentina, Brazil and Peru) The World Bank Working Papers WPS 0999

Granger, Clive W.J. " Developments in the Study of Cointegrated Economic Variables." Oxford Bulletin of Economics and Statistics 48,3 (1986), 213-228

Kravis, I.B., Kennesey, Z.,Heston, A. and Summers, R. "A system of International Comparisons of Gross Product and Purchasing Power" Baltimore: John Hopkings Press, 1975 .

Kouri, Pennti J.K. 1976. " The exchange Rate and the Balance of Payments in the Short Run and in the Long Run: A Monetary Approach" Scandinavian Journal of Economics, Vol. 78, No 2, (1976), pp. 280-304.

Lago, Ricardo. 1991. "The Illusion of Pursuing Redistribution Through Macropolicies: Peru's Heterodox Experience (1985-1990) in R. Dornbusch and S Edwards editors, The Macroeconomics of Populism in Latin America. Chicago, University of Chicago Press. 
Lee, Taebong. 1992. "Exchange Rates, Capital Mobility and Currency Substitution," Ph.D. Dissertation. Texas A\&M University.

Liviatan, Nissan, 1981. "Monetary Expansion and Real Exchange Rate Dynamics," Journal of Political Economy, Vol. 89, No. 6, 1218-1227.

MacDonald, Ronald. 1995. "Long Run Exchange Rate Modeling, A survey of Recent Evidence" IMF Staff Papers. Vol. 42, No3, September.

Mark, Nelson C. "Real and Nominal Exchange Rates in the Long Run: An Empirical Investigation". Journal of International Economics 28, (1990), 115-136.

Miller, Stephen M. "Monetary Dynamics: An application of Cointegration and ErrorCorrection Modeling." Journal of Money, Credit, and Banking Vol. 23, No 2 (May 1991 1), 139-154.

McNown, Robert, and Myles S. Wallace. "Cointegration Tests for Long Run Equilibrium in the Monetary Exchange Rate Model" Economic Letters 31 (December 1989), 263-267

McNown, Robert, and Myles S. Wallace. "Cointegration Tests of the Monetary Exchange Rate Model for Three High-Inflation Economies" Journal of Money, Credit, and Banking Vol. 26, No 3 (August 1994 part 1), 396-411.

McNown, Robert, and Myles S. Wallace. "Cointegration Tests of a Long-Run Relation Between Money Demand and the Effective Exchange Rate" Journal of International Money and Finance Vol. 11, (1992), 107-114.

Morales, Juan Antonio. 1988. "Inflation and Stabilization in Bolivia" in eds. Michael Bruno, Stanley Fisher, Rudiger Dornbusch \& Guido Di Tella. "Inflation and Stabilization" The MIT Press.

Morales, Juan Antonio. 1992. "The transition from Stabilization to Sustained Growth in Bolivia" in eds. Michael Bruno, Stanley Fisher, Elhanan Helpman and Nissan Liviatan. "Lessons from Economic Stabilization and Its Aftermath" The MIT Press.

Modiano, Eduardo, 1988. "The Cruzado First Attempt: The Brazilian Stabilization Program of February 1986." in eds. Michael Bruno, Stanley Fisher, Rudiger Dornbusch \& Guido Di Tella. "Inflation and Stabilization" The MIT Press.

Nurkse, Ragnar. 1945. Conditions of International Monetary Equilibrium. essays in International Finance, No 4 (spring), International Finance Section, Princeton University. [Reprinted in Ellis, Howard S. and Lloyd A. Meltzer, eds., Readings in the Theory of International Trade, American Economic Association, Homewood, Illinois (Richard D. Irwin, 1950)]. 
Obstfeld, Maurice and Kenneth Rogoff, 1995. "Exchange Rate Dynamics Redux," Journal of Political Economy, vol. 103, no. 3, pp. 624-660.

Patinkin, Don. 1993. "Israel's Stabilization Program of 1985, Or Some Simple Truths of Monetary Theory" Journal of Economic Perspectives. Vol. 7, Number 2 pp. 103-128

Phillips, Peter C. and Mico Loretan. "Estimating Long-Run Economic Equilibria." Review of Economic Studies Vol. 58, (1991), pp. 407-436.

Sachs, Jeffry. 1989. Social Conflict and Populist Policies in Latin America. NBER Working Paper No. 2897. Cambridge Mass.

Stockman, A.C. "Risk, Information, and Forward Exchange Rates", in The Economics of Exchange Rates: Selected Studies, (eds.) J.A. Frenkel and H.G. Johnson, Reading, Massachusetts, 1978.

Taylor, Mark. "An Empirical Examination of Long-Run Purchasing Power Parity Using Cointegration Techniques" Applied Economics, Vol. 20, 1988, pp. 1369-81.

Whitt, Jr. Joseph A. "The Long-Run Behavior of the Real Exchange Rate: A Reconsideration" Journal of Money, Credit, and Banking Vol. 24, No 1 (Feb. 1994), 7382.

Williamson, John 1985. "The Exchange rate System: Policy Analysis in International Economics 5". Washington: Institute for International Economics.

Williamson, John 1991. "FEERs and the ERM" National Institute Economic Review (August).

Wren-Lewis, Simon. 1992. "On the Analytical Foundations of the Fundamental Equilibrium Exchange Rate" In C.P. Hargreaves, ed., Macroeconmic Modeling of the Long Rum, pp. 323-38. Aldershot, England: Edward Elgar.

Zou, Heng-Fu. 1993. "Dollarization and Inflation in a Two-Country Optimization Model. Journal of International Money and Finance. Vol. 12. pp. 209-220. 


\section{RAFAEL AMIEL-SAENZ}

EDUCATION

EXPERIENCE

1996

$1987-1989$

1996

1995

1993-1995

1992

1995
Ph.D. in Economics

Florida International University.(FIU) December 1996

Courses in Business \& Public Finance and Data Analysis.

W. Averell Harriman School for Management and Policy

State University of New York at Stony Brook. Spring 1992

M.A. in Economics (Industrial Organization)

State University of New York at Stony Brook. December 1991

B.A., Economics. June 1988

Title of Economist, granted September 1989.

University of Lima-Peru.

\section{Academic}

University of Lima-Peru. Department of Economics.

Assistant Professor, Resource Allocation and Welfare Economics; Special Topics in Economics (undergraduate) Teaching Assistant for Financial Mathematics (undergraduate level)

Florida International University. Department of Economics.

Adjunct Professor Economics and Society course (undergrad level)

Instructor, Economics and Society course (undergraduate level)

Instructor, Economics of Latin America. Master's Program.

School of Journalism.

Teaching Assistant, for Econometrics I (graduate level) Instructor, Microeconomics Principles course (undergraduate level)

\section{Research}

Research Assistant, Center for Labor Research \& Studies.

Florida International University.

Projects: Impact of the Dominican Community in Miami's

Economy

Effects of NAFTA on the labor force of Florida. 
Research Assistant, Department of Economics, Florida International University

Projects:- Small Businesses in Mexico, an empirical study

- The Economy of Florida.

1990

1987-1989

Researcher, Economic Analysis Group, La Moneda

Corporation. Lima-Peru.

- Responsible for the Public Finance Monthly Report.

- Project Evaluation

Research Assistant, Economic \& Social Research Center, University of Lima-Peru.

In charge of the Public Sector analysis for trend reports.

Additional Projects:

- Imports Liberalization and Industrial Production

- Multiple Exchange Rate, Money Creation and Fiscal Deficit

\section{Business}

1997

Hamilton Bank NA, Miami

Senior Economist

1996

1993-1995 Business and Economics Analysts, Inc. Miami, Florida.

ADEX- University of Lima

Consultant, project: Exchange Rate Appreciation and

Unemployment.

Financial Analyst, project evaluation and actuarial analysis.

1986

Continental Bank, Planning \& Projects Department

Assistant, Evaluation of projects for new branches.

PUBLICATIONS - Multiple Exchange Rate, Money Creation and Fiscal Deficit. May 1990. CIESUL. Lima-Peru.

- Imports Liberalization and Industrial Production: A behavioral model. July 1988. CIESUL. Lima-Peru.

- Economic Trend Analysis. May, 1988. CIESUL. Lima-Peru.

- Economic Trend Analysis. Nov., 1987 CIESUL. Lima-Peru.

COMPUTER

SKILLS
Working knowledge of Lotus 123, Microsoft Word, Excel WordPerfect, MicroTSP (Time Series Processor), Statistix Harvard Graphics in both environments DOS and Windows.

Native Language: Spanish. Fluent in English.

- University of Lima: Graduate Fellowship. Stony Brook 
- Fulbright Commission: Travel Fellowship. Stony Brook

- Graduate Assistantship. Dpt. of Economics. Stony Brook

- Graduate Assistantship. Dpt. of Economics, FIU.

- Latin-American Leadership Seminar. DenverColorado.USAID

- President of the Graduate Economics Student Association. FIU. 
